Prepared in cooperation with the

City of Seward, Nebraska

\title{
Ground-Water Age and Quality in the High Plains Aquifer near Seward, Nebraska, 2003-04
}

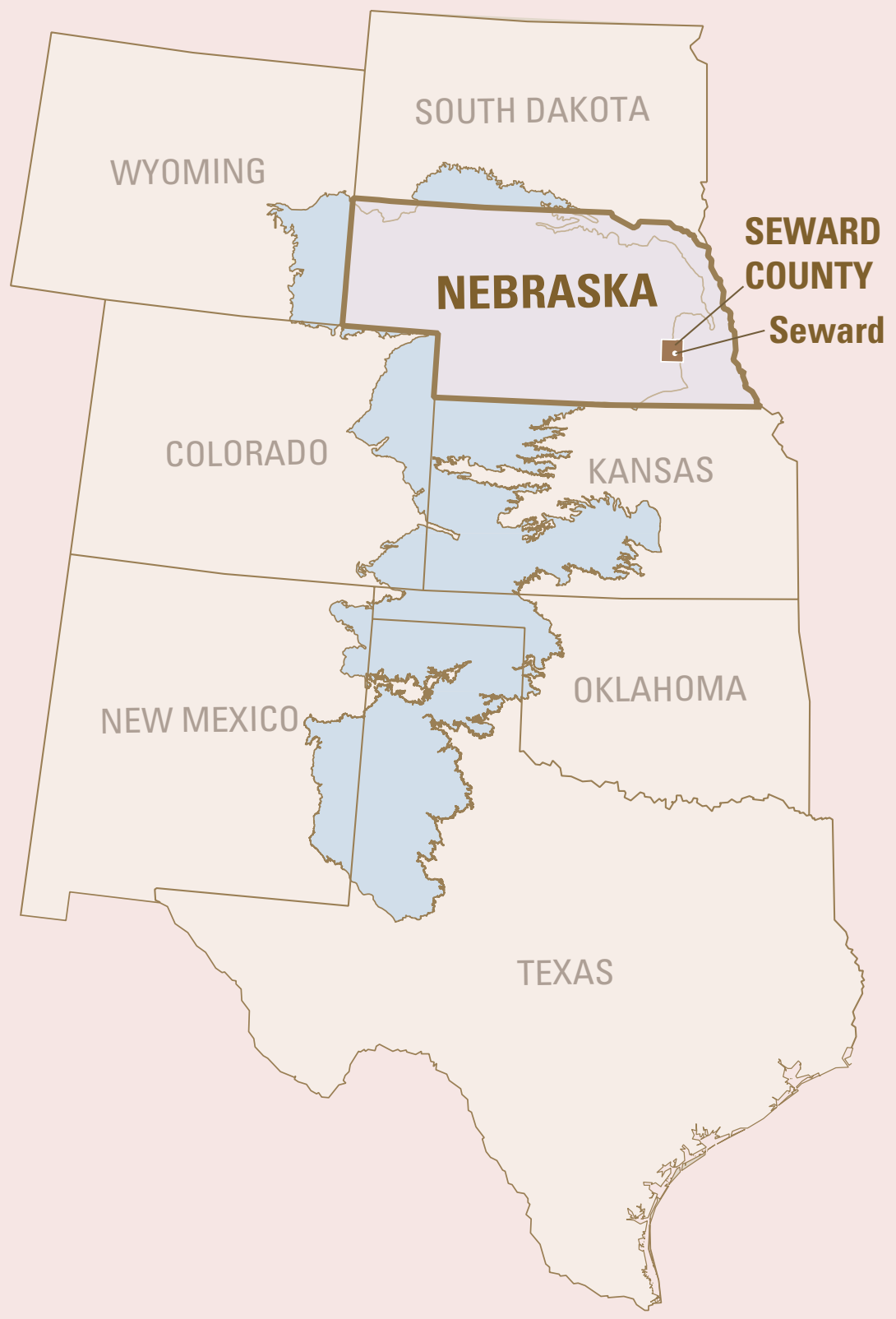

Scientific Investigations Report 2007-5088 



\section{Ground-Water Age and Quality in the High Plains Aquifer near Seward, Nebraska, 2003-04}

By Jennifer S. Stanton, Matthew K. Landon, and Michael J. Turco

Prepared in cooperation with the City of Seward, Nebraska

Scientific Investigations Report 2007-5088 


\section{U.S. Department of the Interior DIRK KEMPTHORNE, Secretary}

\section{U.S. Geological Survey \\ Mark D. Myers, Director}

\section{U.S. Geological Survey, Reston, Virginia: 2007}

For product and ordering information:

World Wide Web: http://www.usgs.gov/pubprod

Telephone: 1-888-ASK-USGS

For more information on the USGS — the Federal source for science about the Earth, its natural and living resources, natural hazards, and the environment:

World Wide Web: http://www.usgs.gov

Telephone: 1-888-ASK-USGS

Any use of trade, product, or firm names is for descriptive purposes only and does not imply endorsement by the U.S. Government.

Although this report is in the public domain, permission must be secured from the individual copyright owners to reproduce any copyrighted materials contained within this report.

Suggested citation:

Stanton, J.S., Landon, M.K., and Turco, M.J., 2007, Ground-water age and quality in the High Plains aquifer near Seward, Nebraska, 2003-04: U.S. Geological Survey Scientific Investigations Report 2007-5088, 37 p.

Back cover:

Top photograph shows USGS personnel drilling a monitoring well. Middle photograph shows USGS personnel sampling a monitoring well. Bottom photograph shows monitoring well protective cover. 


\section{Contents}

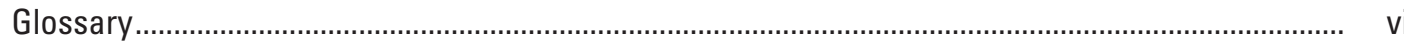

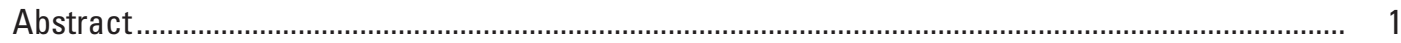

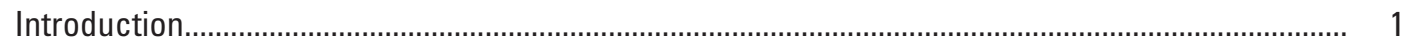

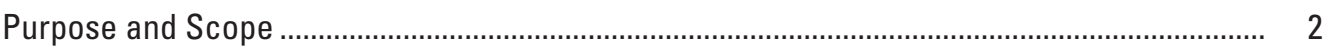

Description of Study Area .............................................................................................. 2

Previous Investigations............................................................................................. 2

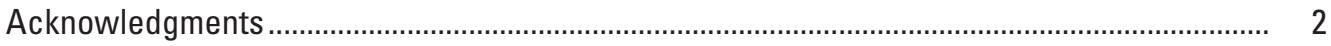

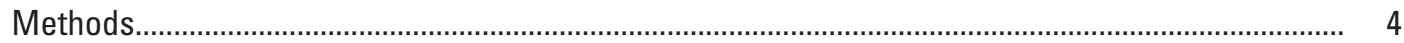

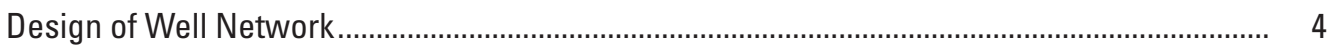

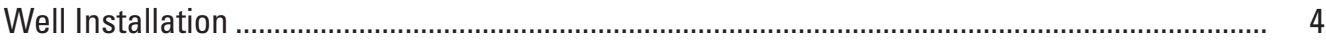

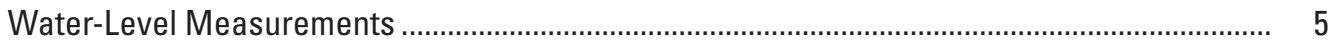

Collection and Analysis of Water Samples ..................................................................... 5

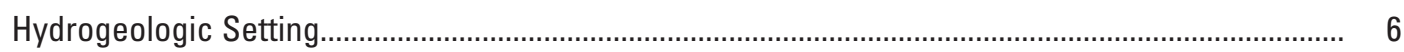

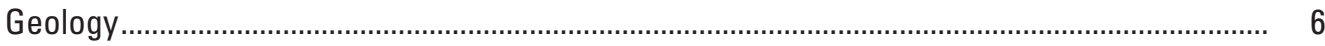

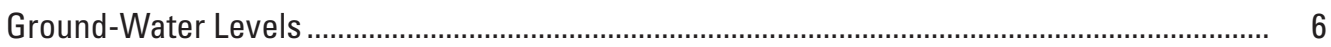

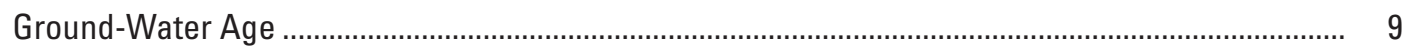

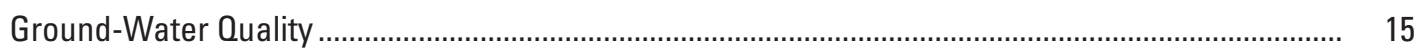

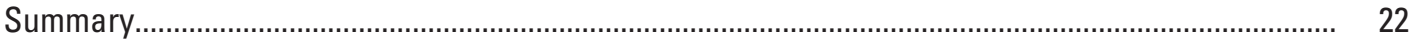

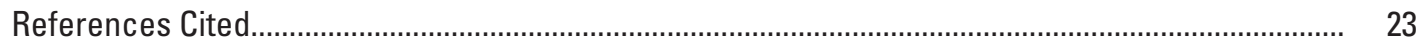

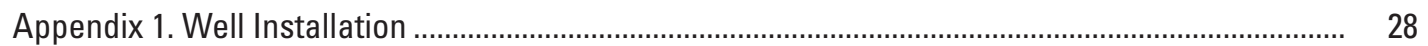

Appendix 2. Estimation of Ground-Water Age …….................................................................... 30

\section{Figures}

1. Map showing location of study area and monitoring-well nests near Seward, Nebraska, and observation wells measured in spring 2001 by Upper Big Blue Natural Resources District.

2. Hydrogeologic sections along two ground-water flow paths upgradient from Seward west well field

3. Map showing water-level contours near Seward, Nebraska, spring 2001.

4. Graphs showing water levels measured in monitoring-well nests near Seward, Nebraska, July 2004 to March 2006

5. Hydrogeologic sections showing best estimate of apparent mean recharge date and percentage of sample composed of young water for ground-water samples collected near Seward, Nebraska, 2003-04

6. Graphs showing relations of depth below land surface to $(A)$ apparent recharge date or mean recharge date of water, and $(B)$ fraction of sample composed of young water for ground-water samples collected near Seward, Nebraska, 2003-04.

7. Trilinear diagrams showing relative proportions, in percentage equivalents, of major ions in ground-water samples collected from monitoring and supply wells with respect to areal position and depth below land surface near Seward, Nebraska, 2003-04.

8. Hydrogeologic sections showing nitrate concentrations in ground-water samples collected from monitoring wells near Seward, Nebraska, August 2004, and supply well W11, November 2003 
9. Hydrogeologic sections showing dissolved-solids concentrations in ground-water samples collected from monitoring wells near Seward, Nebraska, August 2004, and supply well W11, November 2003.

10. Graphs showing relations between apparent recharge date and $(A)$ measured nitrate concentrations and $(B)$ nitrate concentrations of young water adjusted for mixing in ground-water samples collected near Seward, Nebraska, compared to historical nitrogen fertilizer applications in Seward County, Nebraska......

2-1. Graph showing ratio of measured tritium concentration to calculated initial tritium concentration before decay compared to tritium concentration in ground-water samples collected from monitoring wells near Seward, Nebraska, and values indicated by piston-flow and exponential-mixing models.

2-2. Graph showing concentration of chloroflorocarbon-12 compared to tritium concentration in ground-water samples collected from monitoring and supply wells near Seward, Nebraska, and values indicated by piston-flow and exponential-mixing models.

2-3. Graph showing concentration of sulfur hexafluoride compared to tritium concentration in ground-water samples collected from monitoring wells near Seward, Nebraska, and values indicated by piston-flow and exponential-mixing models

2-4. Graph showing ground-water mean recharge dates determined using tritium/helium and chlorofluorocarbon-12 techniques in ground-water samples collected from monitoring wells near Seward, Nebraska.

\section{Tables}

1. Estimates of age and mixing fractions for ground-water samples collected near Seward, Nebraska, 2003-04.

2. Physical properties and concentrations of selected inorganic constituents and detected pesticide compounds in untreated ground water collected from supply wells near Seward, Nebraska, November 2003.

3. Physical properties and concentrations of selected inorganic constituents in groundwater samples collected from monitoring wells near Seward, Nebraska, August 2004....

4. Well-construction information for monitoring wells near Seward, Nebraska..... 18

5. Dissolved-gas concentrations and estimated recharge temperatures and excess air quantities in ground-water samples collected from monitoring and supply wells near Seward, Nebraska, 2003-04.

6. Tracer data used in estimating ground-water age near Seward, Nebraska, 2003-04 ....... 


\section{Conversion Factors, Abbreviations, and Datums}

\begin{tabular}{|c|c|c|}
\hline Multiply & By & To obtain \\
\hline \multicolumn{3}{|c|}{ Length } \\
\hline inch (in.) & 2.54 & centimeter $(\mathrm{cm})$ \\
\hline inch (in.) & 25.4 & millimeter $(\mathrm{mm})$ \\
\hline foot (ft) & 0.3048 & meter $(\mathrm{m})$ \\
\hline mile (mi) & 1.609 & kilometer $(\mathrm{km})$ \\
\hline \multicolumn{3}{|c|}{ Area } \\
\hline acre & 4,047 & square meter $\left(\mathrm{m}^{2}\right)$ \\
\hline acre & 0.004047 & square kilometer $\left(\mathrm{km}^{2}\right)$ \\
\hline square mile $\left(\mathrm{mi}^{2}\right)$ & 2.590 & square kilometer $\left(\mathrm{km}^{2}\right)$ \\
\hline \multicolumn{3}{|c|}{ Volume } \\
\hline gallon (gal) & 0.003785 & cubic meter $\left(\mathrm{m}^{3}\right)$ \\
\hline cubic foot $\left(\mathrm{ft}^{3}\right)$ & 0.02832 & cubic meter $\left(\mathrm{m}^{3}\right)$ \\
\hline \multicolumn{3}{|c|}{ Volume per unit mass } \\
\hline cubic centimeter per gram $\left(\mathrm{cm}^{3} / \mathrm{g}\right)$ & 0.01602 & cubic foot per pound $\left(\mathrm{ft}^{3} / \mathrm{lb}\right)$ \\
\hline \multicolumn{3}{|c|}{ Mass } \\
\hline pound (lb) & 0.4536 & kilogram (kg) \\
\hline pound per acre (lb/acre) & 1.120 & kilogram per hectare $(\mathrm{kg} / \mathrm{ha})$ \\
\hline pound per year (lb/yr) & 0.4536 & kilogram per year $(\mathrm{kg} / \mathrm{yr})$ \\
\hline
\end{tabular}

Temperature in degrees Celsius $\left({ }^{\circ} \mathrm{C}\right)$ may be converted to degrees Fahrenheit $\left({ }^{\circ} \mathrm{F}\right)$ as follows:

$$
{ }^{\circ} \mathrm{F}=\left(1.8 \times^{\circ} \mathrm{C}\right)+32 .
$$

Temperature in degrees Fahrenheit $\left({ }^{\circ} \mathrm{F}\right)$ may be converted to degrees Celsius $\left({ }^{\circ} \mathrm{C}\right)$ as follows:

${ }^{\circ} \mathrm{C}=\left({ }^{\circ} \mathrm{F}-32\right) / 1.8$.

Vertical coordinate information is referenced to the North American Vertical Datum of 1988 (NAVD 88).

Horizontal coordinate information is referenced to the North American Datum of 1983 (NAD 83). Altitude, as used in this report, refers to distance above the vertical datum.

Specific conductance is given in microsiemens per centimeter at 25 degrees Celsius $(\mu \mathrm{S} / \mathrm{cm}$ at $\left.25^{\circ} \mathrm{C}\right)$.

Concentrations of chemical constituents in water are given either in milligrams per liter (mg/L) or micrograms per liter $(\mu \mathrm{g} / \mathrm{L})$. 


\section{Glossary}

Alluvial valley A valley filled with stream-deposited sediment.

Contributing area The area contributing recharge to a discharging well is the area at the water table where water entering the ground-water flow system will eventually be removed by the well.

Denitrification A process by which oxidized forms of nitrogen such as nitrate $\left(\mathrm{NO}_{3}^{-}\right)$are reduced to form nitrogen oxides or free nitrogen, commonly brought about by the action of denitrifying bacteria.

Hydraulic head The height of the free surface of a body of water above a given point beneath the surface.

Hydraulic-head gradient The change of hydraulic head per unit of distance in a given direction.

Oxic geochemical conditions The state of the geologic and chemical environment when ground water has a concentration of dissolved oxygen equal to or greater than 1.0 milligram per liter.

Terrigenic From the earth's crust and mantle sources, nonatmospheric.

Upgradient Indicating a location with a higher ground-water hydraulic head along a ground-water flow path than a reference point along the flow path having a lower ground-water hydraulic head such as a discharging well. 


\title{
Ground-Water Age and Quality in the High Plains Aquifer near Seward, Nebraska, 2003-04
}

\author{
By Jennifer S. Stanton, Matthew K. Landon, and Michael J. Turco
}

\section{Abstract}

The U.S. Geological Survey, in cooperation with the City of Seward, Nebraska, conducted a study of ground-water age and quality to improve understanding of: (1) traveltimes from recharge areas to public-supply wells, (2) the effects of geochemical reactions in the aquifer on water quality, and (3) how water quality has changed historically in response to landuse practices. Samples were collected from four supply wells in the Seward west well field and from nine monitoring wells along two approximate ground-water flow paths leading to the well field. Concentrations of three different chlorofluorocarbons (CFC-12, CFC-11, and CFC-113), sulfur hexafluoride $\left(\mathrm{SF}_{6}\right)$, and ratios of tritium $\left({ }^{3} \mathrm{H}\right)$ to helium-3 $\left({ }^{3} \mathrm{He}\right)$ isotope derived from radioactive decay of ${ }^{3} \mathrm{H}$ were used to determine the apparent recharge age of ground-water samples. Age interpretations were based primarily on ${ }^{3} \mathrm{H} /{ }^{3} \mathrm{He}$ and $\mathrm{CFC}-12$ data. Estimates of apparent ground-water age from tracer data were complicated by mixing of water of different ages in 10 of the 13 ground-water samples collected.

Apparent recharge dates of unmixed ground-water samples or mean recharge dates of young fractions of mixed water in samples collected from monitoring wells ranged from 1985 to 2002. For monitoring-well samples containing mixed water, the fraction of the sample composed of young water ranged from 26 to 77 percent of the sample. Apparent mean recharge dates of young fractions in samples collected from four supply wells in the Seward west well field ranged from about 1980 to 1990. Estimated fractions of the samples composed of young water ranged from 39 to 54 percent. It is implicit in the mixing calculations that the remainder of the sample that is not young water is composed of water that is more than 60 years old and contains no detectable quantities of modern atmospheric tracers. Estimated fractions of the mixed samples composed of "old" water ranged from 23 to 74 percent. Although alternative mixing models can be used to interpret the results, the mean age and mixing fractions from the primary mixing models used were fairly similar.

Relations of ground-water age and nitrate concentrations to depth were not consistent across the study area. In some well nests, more young water and nitrate were present near the bottom than in the middle of the aquifer. These results probably reflect pumping from irrigation and supply wells, which are screened primarily in the lower part of the aquifer, and draw younger water downward in the aquifer. Substantial mixing probably occurs because the aquifer is relatively thin (50 feet) and has a relatively high density of wells (about five pumping wells per square mile). The most reliable estimate of horizontal traveltimes based on differences in groundwater ages between a shallow monitoring well at the upgradient end of the northwest well transect and the deep well at the downgradient end of the well transect was 9 years to travel a distance of about 2 miles. The general similarity of ages at similar depths between different well nests is consistent with the fact that horizontal flow in the aquifer is relatively rapid.

Concentrations of nitrate (as nitrogen) in untreated ground-water samples from supply wells in the well field were larger than the U.S. Environmental Protection Agency Maximum Contaminant Level for drinking water of $10 \mathrm{mg} / \mathrm{L}$ (milligrams per liter), ranging from 11.3 to $13.5 \mathrm{mg} / \mathrm{L}$. It is unlikely that nitrate concentrations in the aquifer near the Seward west well field are decreased by denitrification in the aquifer due to oxic geochemical conditions that preclude this reaction. Nitrate concentrations coupled with water recharge dates were compared to historical estimated fertilizer application in an attempt to reconstruct historical trends in ground-water nitrate concentrations and their relation to land-use practices. Nitrate concentrations in young-water fractions, after adjustment for mixing, may be decreasing over apparent recharge dates of 1980 to 2002 , corresponding to a period of generally decreasing nitrogen fertilizer applications.

\section{Introduction}

Ground water is a source of drinking water for most communities in Nebraska. Ground-water supplies are vulnerable to contamination from agricultural, industrial, and other activities as a result of percolation of contaminants downward from the land surface to the water table. Once in the ground-water system, water and contaminants move from the recharge area to the discharge area, which may be a supply well. Evaluating the amount of time it takes water deposited at the land surface to reach a supply well can yield useful information regarding 
contaminant transport and quality of local and regional ground water.

The citizens of Seward, in southeastern Nebraska, depend on ground water from Quaternary-age deposits of the High Plains aquifer for drinking water. Nitrate (as nitrogen) concentrations in the aquifer have been increasing over the past decade and have approached the U.S. Environmental Protection Agency Maximum Contaminant Level of $10 \mathrm{mg} / \mathrm{L}$ in some wells (Paul Dammann, Water/Wastewater Superintendent, City of Seward, Nebraska, oral commun., July 17, 2002). Increased nitrate concentrations have been particularly problematic in the Seward west well field, located approximately $3 \mathrm{mi}$ west of Seward. The increase in nitrate concentrations has led city and county water managers to initiate a process to develop a nutrient management plan in the areas contributing recharge to supply wells.

The U.S. Geological Survey, in cooperation with the City of Seward, Nebraska, conducted a 2-year study from 2003 through 2004 of ground-water age and quality to improve understanding of: (1) traveltimes from recharge areas to supply wells, (2) the effects of geochemical reactions in the aquifer on water quality, and (3) how water quality has changed historically in response to land-use practices. Age of ground water in supply wells in the Seward west well field and along two ground-water flow paths upgradient from the well field was determined to estimate time of travel from recharge areas to supply wells. Concentrations of nitrate, dissolved gases, and other geochemical constituents along flow paths to the supply wells were used to assess the extent to which denitrification affects nitrate concentrations in the aquifer. Ground-water age and nitrate concentrations were used to estimate historical changes in nitrate loading to the aquifer.

\section{Purpose and Scope}

The purpose of this report is to document ground-water age and selected water-quality characteristics along approximate ground-water flow paths in the High Plains aquifer near Seward, Nebraska. This report includes a brief description of the design of the local monitoring-well network and methods of data collection and analysis. The report describes the steps in estimating ground-water age using atmospheric tracers and describes the distribution of the estimated ground-water ages. General water-quality characteristics, with particular emphasis on nitrate, are described. Nitrate concentrations in ground water of different recharge ages are compared to estimated historical fertilizer applications. In addition, ground-waterlevel measurements were collected approximately monthly beginning in July 2004 to compare spatial and temporal variations in ground-water levels and flow patterns to ground-water age and chemistry data. The data through March 2006 are described in this report.

\section{Description of Study Area}

The study area is located west of the Big Blue River in central Seward County, Nebraska (fig. 1). Seward County is characterized by nearly flat or rolling upland dissected by a network of valleys formed from water erosion (Keech, 1978). Surficial geologic materials in Seward County include till (a glacially deposited mixture of clay, sand, gravel, and stones of all sizes), loess (windblown silt or clay, typically deposited during glacial periods), and stream-deposited sand and gravel. The study area is located in an area of relatively flat upland loess. Soils derived from this loess readily absorb and retain water but also allow water to move downward and recharge the aquifer.

The climate of Seward County is subhumid, receiving mean annual precipitation of 27.4 in. between 1949 and 2002 (Nebraska Department of Natural Resources, 2002). Precipitation can vary substantially from year to year; mean annual precipitation ranged from 16.4 in. in 1955 to 41.4 in. in 1993. Most precipitation occurs during the frost-free period.

Land use in the area is dominated by agriculture. In 2002, about 83 percent of Seward County was used for growing crops (National Agricultural Statistics Service, 2002). About 42 percent of cropland was irrigated. The primary crops grown were corn and soybeans. Agricultural chemicals, including nitrogen fertilizer, are applied in Seward County to maximize crop yields. There were more than 1,300 active irrigation wells in Seward County in 2006 (Nebraska Department of Natural Resources, 2006). Most irrigation wells are in the High Plains aquifer, west of the Big Blue River. In the study area, the average density of irrigation wells is about 4.75 wells per square mile (fig. 1).

\section{Previous Investigations}

Gottula (1990) described the hydrogeology and groundwater quality of the eastern part of the Upper Big Blue Natural Resources District (UBBNRD), which encompasses the study area. The spatial and temporal distribution of water quality in the aquifer in the UBBNRD was described by Verstraeten and others (1998). The basic hydrogeology of Seward County was described by Keech (1978). Regional hydrogeologic investigations including the study area were conducted by Johnson and Keech (1959) and Gutentag and others (1984). Several ground-water modeling investigations at various scales encompassing the study area (Emery, 1966; Huntoon, 1974; Cady and Ginsburg, 1979; Nebraska Natural Resources Commission, 1983; Alley and Emery, 1986; Luckey and others, 1986) contributed to the understanding of the ground-water hydrology in the area.

\section{Acknowledgments}

The authors would like to thank Paul Dammann, the now retired former Director of the City of Seward Public 

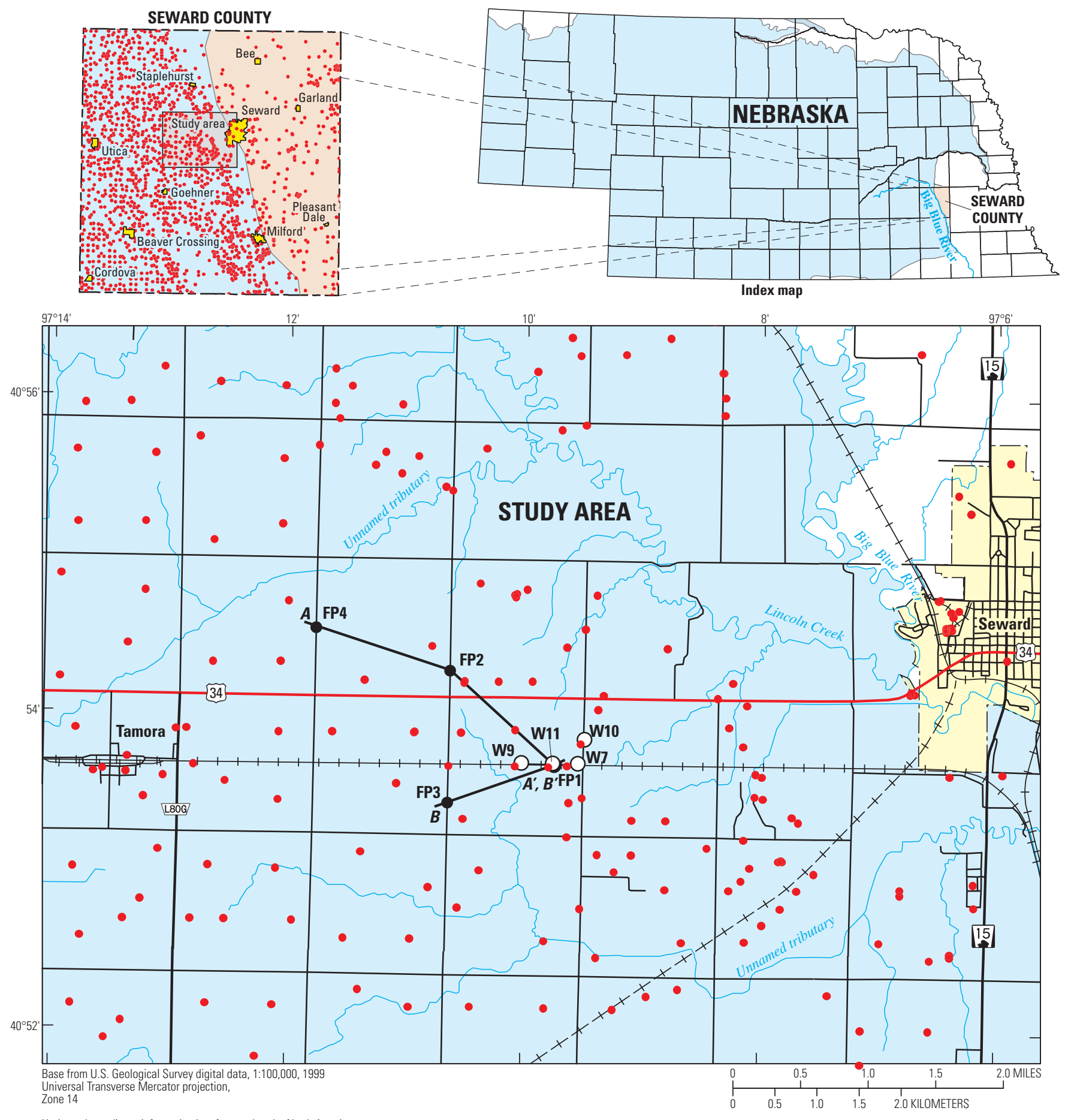

Horizontal coordinate information is referenced to the North American Datum of 1983 (NAD 83)

EXPLANATION

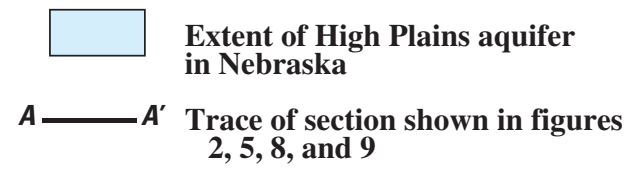

FP2 Monitoring-well nest location and well-nest identifier

W11 $\mathrm{O}$ Supply well and identifier

- Well

Figure 1. Location of study area and monitoring-well nests near Seward, Nebraska, and observation wells measured in spring 2001 by Upper Big Blue Natural Resources District. 
Utilities Department, for his pivotal role in initiating this study, his willingness to provide institutional knowledge about the ground-water resources in the Seward area, and his unwavering dedication to the protection of the valuable resource. The authors would also like to thank the landowners who allowed monitoring-well nests to be installed on their property without which the study would not have been possible.

\section{Methods}

\section{Design of Well Network}

Monitoring-well nests were installed along estimated ground-water flow paths leading to the Seward west well field. Ground-water flow paths were estimated from water-table altitude maps from different sources including output from a simple mathematical model for delineating the wellhead protection areas (WHPAs) for the west well field (Bill Lukash, Nebraska Department of Environmental Quality (NDEQ), written commun., 2001), published maps (Keech, 1978; Cady and Ginsberg, 1979), and data compiled for this study (see section on "Ground-Water Levels"). Well nests were installed at different distances from the well field along the estimated ground-water flow paths to represent different traveltimes from the monitoring well to the well field. The selected locations represented traveltimes of less than 30 years and were based on NDEQ model output. Within this constraint, specific monitoring-well locations were selected on the basis of accessibility.

The four supply wells in the Seward west well field are located within $0.5 \mathrm{mi}$ of each other (fig. 1), have contributing recharge areas that are directly affected by ground-water withdrawals, and have had historically similar water chemistry. Therefore, the sampling results from monitoring wells along flow paths leading to the well field can be considered representative of conditions for all four supply wells.

A nest of three monitoring wells each was installed at four sites for the collection of water levels and samples (fig. 1). Each nest of wells consisted of three wells screened at different depths in the aquifer and located within a few feet of each other. These well nests allowed measurement of vertical differences in ground-water levels, chemistry, and age. One well nest (FP1) was located within $100 \mathrm{ft}$ of one of the supply wells (well W11) (probably within the estimated 1-year traveltime to the well) to characterize ground-water age at different depths in the aquifer in the vicinity of a supply well. A second nest (FP2) was installed about $1 \mathrm{mi}$ upgradient from well W11 at about the estimated location of the 10-year traveltime to the well. The third nest (FP4) was located at about the estimated location of the 30-year traveltime, about 2 mi upgradient from supply well W11. A fourth nest (FP3) was installed about $1 \mathrm{mi}$ to the southwest of supply well W11 along a different potential ground-water flow path to the well field. This well nest was installed because analysis of ground-water altitudes indicated that ground-water flow might be converging on the well field from the southwest in addition to the prevailing regional ground-water flow from the northwest (see section on "Ground-Water Levels").

The three wells at each nest were constructed with one well screen placed at the water table (about $70 \mathrm{ft}$ below land surface), one screen placed near the bottom of the aquifer (about $120 \mathrm{ft}$ below land surface), and one screen placed about halfway between the water table and the bottom of the aquifer (about $100 \mathrm{ft}$ below land surface). The exact vertical placement of the screens depended on the location of highly permeable sand and gravel layers in the aquifer, which were determined from lithologic and geophysical logging during well installation.

\section{Well Installation}

Well installation methods were selected to ensure that water-quality samples represented aquifer conditions and that equipment and construction materials were not a source for leaching or sorption of sampled chemicals. Wells were installed with a mud rotary rig by Layne-Western Incorporated (Kearney, Nebraska) under a drilling contract with the City of Seward. Drilling was completed during January 14-24, 2004. While drilling monitoring wells, samples of the aquifer materials were collected at 5-ft intervals to describe the physical characteristics of the aquifer. In addition, geophysical (natural gamma and electrical resistivity) logs were obtained before well casings were installed. Natural gamma and electrical resistivity measurements can identify the relative permeability of the aquifer throughout the well borehole.

Well casings were constructed of 2-in diameter polyvinyl-chloride (PVC) pipe. Wells were constructed with either 5- or 10-ft screens with a 5-ft blank casing and end cap below the screen (Appendix 1, table 4). The annular space (the space between the well casing and the borehole wall) from the bottom of the well to $12 \mathrm{ft}$ below land surface was filled with a silica sand and gravel pack. The remaining annular space was filled with a $10-\mathrm{ft}$ bentonite pellet seal and $2 \mathrm{ft}$ of bentonite/ cement grout. A concrete pad and protective steel cover were placed at the land surface around the well.

After installation, the wells were developed to remove drilling mud from the borehole introduced during the drilling process and to remove fine particles near the well screen that might clog the screen. Immediately after installation, the wells were air surged and pumped for at least 2 hours by the driller or until the water pumped from the well was clear. In June 2004, the wells were revisited with a Waterra purge pump, which surges (introduces pressure waves into) the well, thereby mobilizing fine particles from near the well screen. The monitoring wells were surged and pumped for 2 to 10 hours; 67 to 337 casing volumes were pumped from each well to remove drilling fluid residuals and aquifer fine sediment. Specific conductance and turbidity were monitored during pumping. 


\section{Water-Level Measurements}

Ground-water levels were measured approximately monthly in the monitoring-well nests beginning in July 2004 to compare spatial and temporal variations in ground-water levels and flow patterns to ground-water age and chemistry data. Measurements made through March 2006 are included in this report. Ground-water levels could not be measured at the shallowest monitoring well (FP4-90) in well nest FP4 because the water level was deeper than the bottom of the well screen; at times the shallowest well at well nests FP2 and FP3 also were dry. Water levels were measured using methods described by Garber and Koopman (1968). Data are available in the USGS National Water Information System (NWIS) (U.S. Geological Survey, 2007).

\section{Collection and Analysis of Water Samples}

Water samples were collected from the four supply wells in November 2003 and analyzed for physical properties and concentrations of nitrogen and phosphorus compounds, major ions, trace elements, and selected pesticides. Ground-water age was estimated from concentrations of tritium, chlorofluorocarbons ( $\mathrm{CFCs})$, and sulfur hexafluoride $\left(\mathrm{SF}_{6}\right)$ coupled with interpretation of dissolved gas data (methane, nitrogen, and argon) to estimate recharge temperature. The primary purposes for collecting these samples were (1) to determine if it was feasible to apply ground-water age-dating techniques to water that has recharged the aquifer in the past 60 years and (2) to determine the quality of untreated water from supply wells.

Water samples were collected from 9 of the 12 monitoring wells in August and September of 2004 and analyzed for physical properties, concentrations of nitrogen and phosphorus compounds, and major ions. Ground-water age was determined with concentrations of tritium, selected noble gases [helium-3 $\left({ }^{3} \mathrm{He}\right)$, helium-4 $\left({ }^{4} \mathrm{He}\right)$, and neon], dissolved gases, $\mathrm{CFCs}$, and $\mathrm{SF}_{6}$. Three wells were not sampled because the water table was below the well screen at the time of sampling.

Ground-water samples were collected from wells using procedures described by the USGS National Field Manual (U.S. Geological Survey, variously dated) and the USGS Chlorofluorocarbon Laboratory (U.S. Geological Survey, 2005). Water samples were processed onsite in a mobile laboratory using methods designed to minimize changes to the watersample chemistry. Water was pumped from wells with a submersible pump and delivered to the mobile laboratory through Teflon tubing with stainless-steel connections. Prior to sample collection, stagnant water was flushed from the well by purging at least three casing volumes from the well. While purging, specific conductance, $\mathrm{pH}$, water temperature, turbidity, and dissolved oxygen were measured until readings were stable (U.S. Geological Survey, variously dated). Once readings had stabilized, water samples were collected in precleaned bottles within an enclosed chamber to prevent sample contamination. $\mathrm{CFC}, \mathrm{SF}_{6}$, noble gas, and dissolved gas samples were collected separately from copper tubing attached to the submersible pump; these samples did not contact the atmosphere (U.S. Geological Survey, 2005). To prevent degradation of water samples and maintain the initial concentration of compounds between the time of sample collection and laboratory analyses, contents of the bottles were preserved according to laboratory requirements. Preservation practices differ among chemical constituents and may include chilling, filtration, and (or) chemical treatment (U.S. Geological Survey, variously dated).

Nitrogen and phosphorus compounds (Fishman, 1993; Patton and others, 2003), major ions (Fishman and Friedman, 1989; Fishman, 1993; American Public Health Association, 1998), trace elements (Fishman and Friedman, 1989; Faires, 1993; Garbarino, 1999; and pesticides (Zaugg and others, 1995; Lindley and others, 1996; Sandstrom and others, 2001; Madsen and others, 2003) were analyzed at the USGS National Water Quality Laboratory (NWQL) in Lakewood, Colorado. For samples collected from supply wells in November 2003, tritium analysis was completed by the University of Miami, Tritium Laboratory in Miami, Florida (Östlund, 1987). Dissolved gases, CFCs, and $\mathrm{SF}_{6}$ were analyzed at the USGS Chlorofluorocarbon Laboratory in Reston, Virginia (U.S. Geological Survey Chlorofluorocarbon Laboratory, 2006a,b,c). For monitoring-well samples collected in August 2004, noble gas and tritium analyses were performed at the Lamont-Doherty Earth Observatory of Columbia University in Palisades, New York (Clark and others, 1976; Schloesser and others, 1989).

Quality-control samples were collected to assess the reliability of sample processing and analytical methods. One field-blank sample was collected and analyzed for nitrogen and phosphorus compounds and major ions. Field-blank samples are collected to determine the occurrence and magnitude of sample contamination during sample collection, processing, and transport. Field-blank results indicated that sample contamination was minimal. The only analytes detected in the field-blank sample were calcium $(0.02 \mathrm{mg} / \mathrm{L})$, silica $(0.04 \mathrm{mg} / \mathrm{L})$, and iron (estimated $4 \mu \mathrm{g} / \mathrm{L})$. Calcium and silica concentrations in the field-blank sample were substantially less than environmental sample concentrations. However, the iron concentration was greater than all but two environmental sample concentrations. Therefore, at small concentrations, it was not possible to determine if concentrations of iron in environmental samples were representative of aquifer conditions or the result of sampling contamination. One sequential replicate sample was collected and analyzed for nitrogen and phosphorus compounds, and major ions. Sequential replicate samples are two environmental samples collected one after another within a short period of time to represent a duplication of the same sample water. They are collected to determine variability of the data as a result of sampling and analytical procedures. Replicate sample results support the reliability of the data; all relative differences between constituent concentrations were less than 3 percent. 


\section{Hydrogeologic Setting}

The hydrogeologic setting of the study area includes the composition and distribution of water-bearing layer(s) in the subsurface and the paths followed by ground water from recharge to discharge areas, primarily withdrawals by irrigation and supply wells.

\section{Geology}

The Seward west well field and installed monitoringwell nests are located west of the Big Blue River within the High Plains aquifer (fig. 1). Sand and gravel deposited during the Pleistocene Epoch ( 0.01 to 1.6 million years ago) are the primary water-bearing sediment permitting withdrawal of economically viable quantities of ground water in this area (Keech, 1978; Gottula, 1990; Verstraeten and others, 1998). This sediment is relatively coarse-grained and yields large amounts of water where saturated. Depth to the water table ranges from 75 to $96 \mathrm{ft}$ below land surface in the study area. Loess overlies the sand and gravel and provides a relatively thick layer of fine-grained sediment that may inhibit the downward movement of water to the High Plains aquifer. Beneath the sand and gravel are glacial till, silt, and clay that generally do not yield large quantities of water. Bedrock underlying the study area is the Dakota Sandstone that was deposited during the Early Cretaceous Period (about 96 to 138 million years ago). The Dakota Sandstone is not used extensively for irrigation or public supply in the study area because of high salinity and the requirement of drilling deep wells to reach it.

The physical characteristics of aquifer sediment can affect ground-water flow rates, ground-water age, and groundwater chemistry within the aquifer. Aquifer sediment samples and geophysical logs indicated that the aquifer materials in the immediate vicinity of the monitoring wells were primarily fine to medium sand with intervening layers of clay or silt. Figure 2 shows hydrogeologic sections of the sediment collected from monitoring-well boreholes. A thick layer (between about 40 and $70 \mathrm{ft}$ ) of clay lies between the land surface and the sand deposits. Within the sand deposits, another clay layer about $10 \mathrm{ft}$ thick extends from monitoring-well nest FP1 to well nests FP2 and FP3. Well boreholes did not extend deeper than the top of the glacial till as the overlying sand is the water-bearing layer exclusively screened in the Seward west well field. The saturated thickness of the sand overlying the glacial till is about $50 \mathrm{ft}$ or less, and supply wells generally are screened in the bottom $20 \mathrm{ft}$ of that thickness.

\section{Ground-Water Levels}

Ground-water levels can indicate the vertical and horizontal ground-water flow directions within an aquifer. The ground-water altitude, or hydraulic head in an unconfined aquifer, is a measure of ground-water potential energy.
Because ground water will flow from places with high energy to places with low energy, differences in hydraulic head, or hydraulic-head gradients, are the driving forces that cause water to move from one place to another. The velocity of ground-water flow is proportional to the hydraulic gradient. In the horizontal dimension, ground water will flow from areas with higher hydraulic head to lower hydraulic head. In the vertical dimension, downward gradients cause ground water and contaminants to move downward from the water table into the aquifer.

Several sources of information on ground-water flow direction were considered. Direction of ground-water flow and placement of monitoring wells were determined primarily using ground-water levels measured in spring 2001 by UBBNRD as part of their long-term ground-water-level monitoring program (fig. 3). These data were retrieved from the USGS NWIS (U.S. Geological Survey, 2007) and used to plot ground-water altitudes and draw lines of equal groundwater-level altitude. Ground water moves perpendicular to contour lines of equal ground-water-level altitude. The resulting spring 2001 ground-water-altitude map shows that ground water converged toward the well field from the northwest and southwest. This convergent flow field may be caused by local reductions in hydraulic head within the well field caused by withdrawals from supply wells and nearby irrigation wells. If larger withdrawals of ground water are occurring within the well field than areas to the north and south, ground water will be drawn to the well field.

A ground-water altitude map of Seward County from 1972 (Keech, 1978) shows that regional ground-water flow in the area west of Seward is primarily from west to east but with a substantial southwest-to-northeast component of flow in the vicinity of the Seward west well field. Water-level altitude maps of the UBBNRD from 1975 (Cady and Ginsberg, 1979) and 1996 (Verstraeten and others, 1998) as well as statewide water-level maps from 1979 and 1995 (Conservation and Survey Division of University of Nebraska, 1980, 2000) indicated similar flow directions. Ground-water flow directions in the study area may be affected by the geometry of Lincoln Creek, a tributary to the Big Blue River, and the Big Blue River itself. Both of these streams probably serve as discharge areas for regional ground-water flow (Keech, 1978). These streams, particularly Lincoln Creek, have a northwest-to-southeast orientation immediately to the east and north of the study area (fig. 1), which may cause ground water in the study area to sometimes flow to the northeast towards Lincoln Creek. Thus, the southwest-to-northeast flow component towards the well field may not be related entirely to withdrawals from the well field but may reflect, partially or entirely, a natural shift in the regional ground-water direction close to discharge areas along Lincoln Creek.

It is also likely that temporal changes in recharge and discharge as a result of varying climatic and pumping conditions result in shifts in regional and local ground-water flow directions. Broadly, it appears that there is always regional flow towards the well field from the northwest or west as indicated 


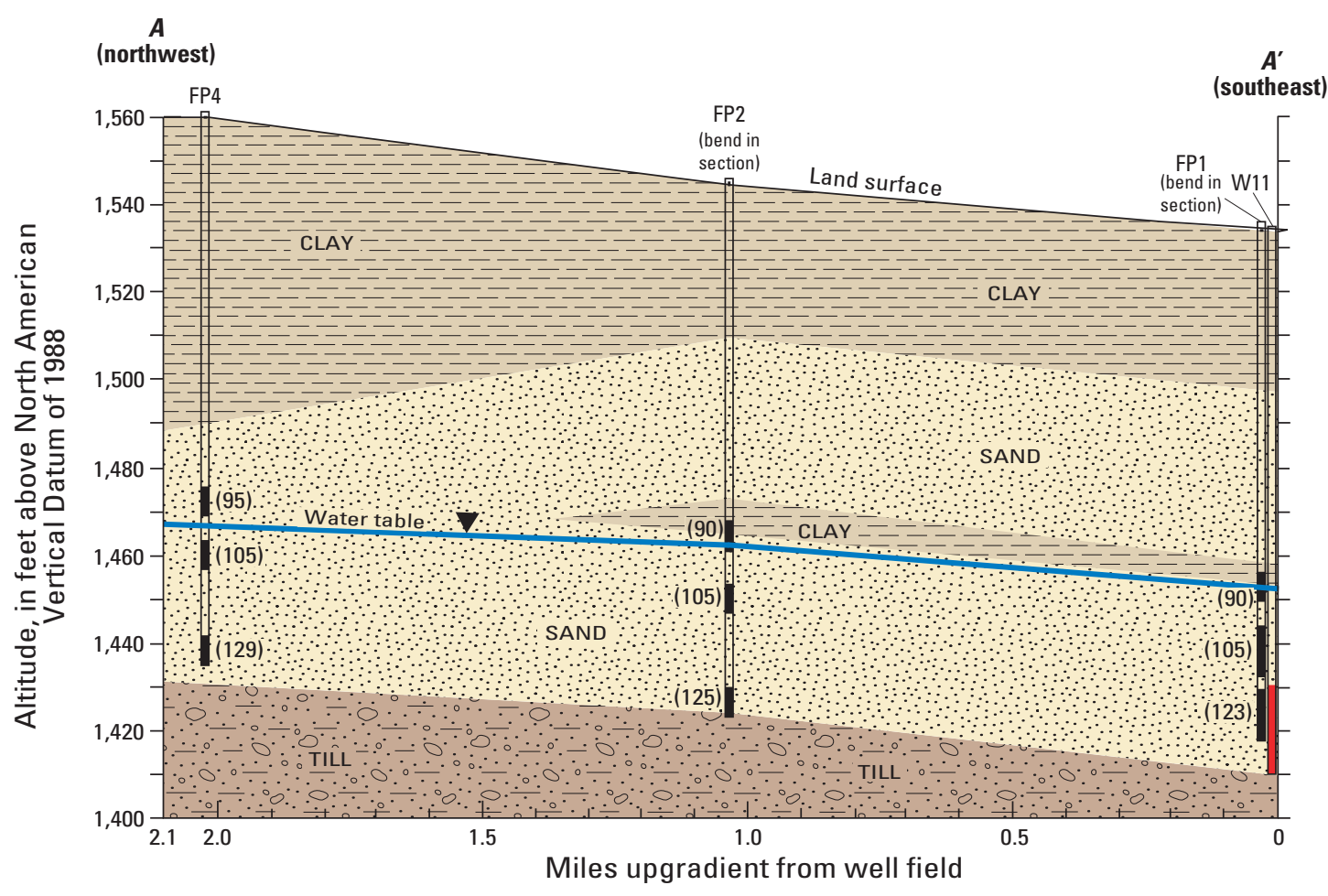

\section{EXPLANATION}

FP3

(90) Monitoring-well screen interval and well-nest identifier-Number in parenthesis ( ) is approximate depth of individual well, in feet below land surface W11

Supply-well screen interval and well identifier

Trace of sections shown in figure 1

Vertical scale greatly exaggerated

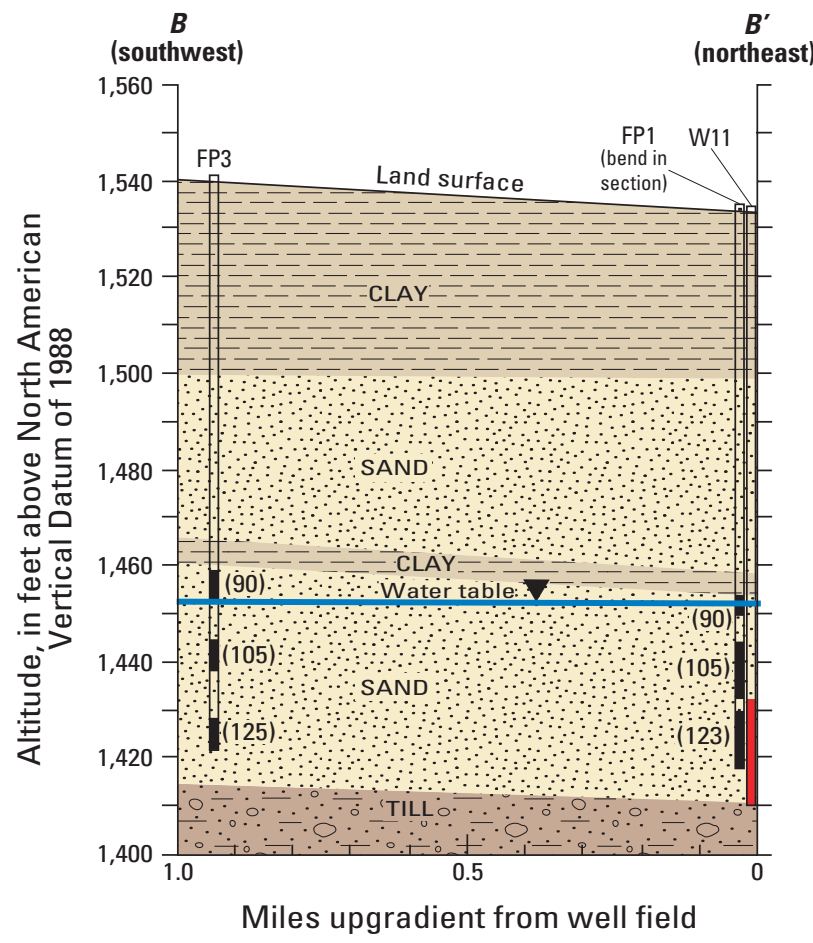

Figure 2. Hydrogeologic sections along two ground-water flow paths upgradient from Seward west well field. 


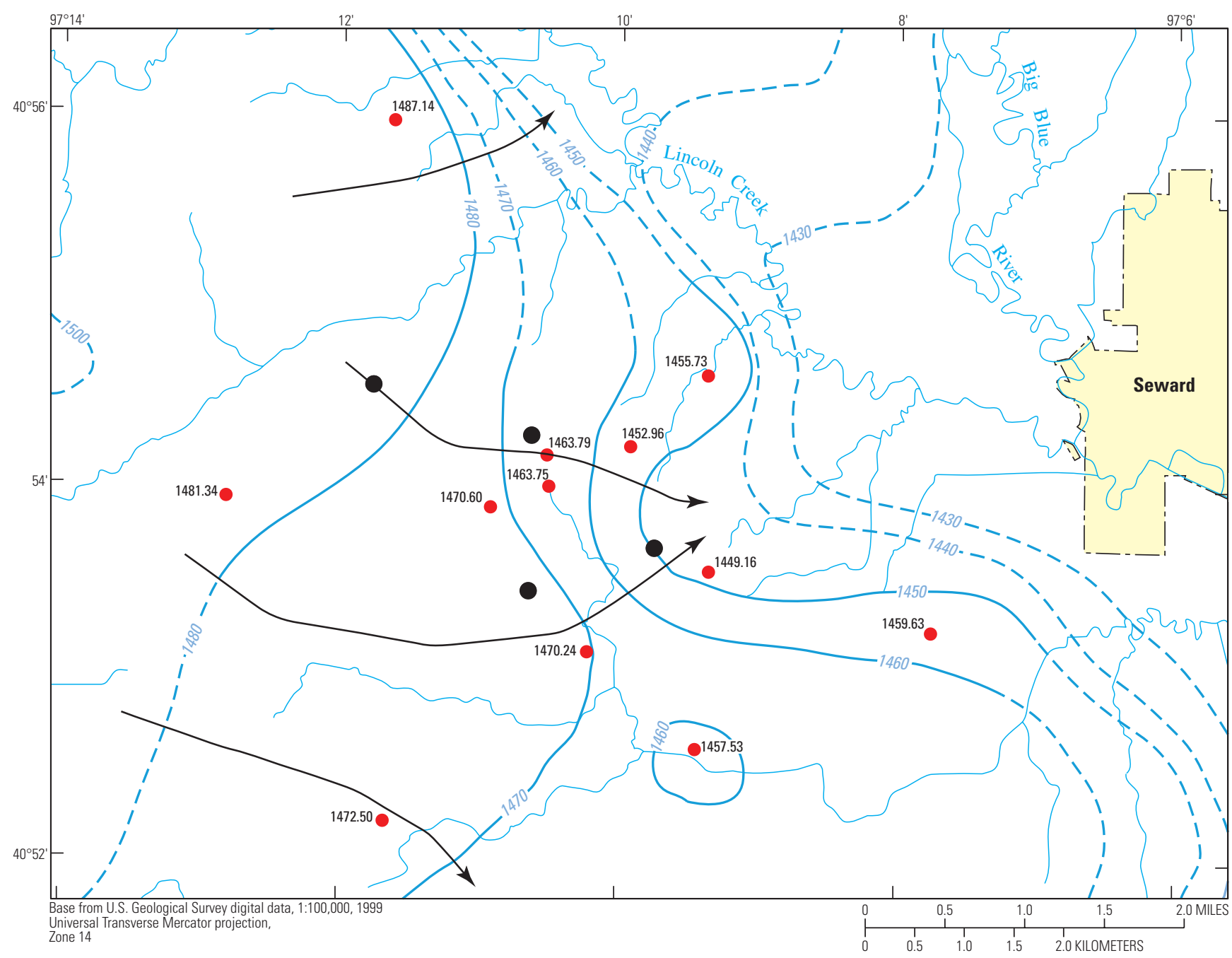

Horizontal coordinate information is referenced to the North American Datum of 1983 (NAD 83)

EXPLANATION

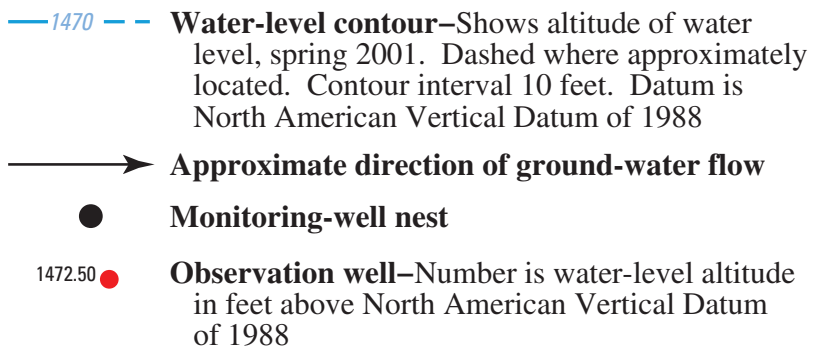

Figure 3. Water-level contours near Seward, Nebraska, spring 2001. Water-level measurements made by Upper Big Blue Natural Resources District.

by the 2001 and other historical water-level maps. Because there is some uncertainty in local ground-water flow directions to the Seward west well field, one of the four monitoring-well nests was installed along a possible ground-water flow path (B-B', fig. 1) from the southwest to compare and contrast ground-water age, quality, and hydraulic head along this flow path with those along a flow path from the northwest (A-A', fig. 1).
Depths to water in the monitoring wells ranged from 74.7 to $95.9 \mathrm{ft}$ below land surface (U.S. Geological Survey, 2007). Water levels changed seasonally, declining during the summer (peak irrigation months) and recovering during the fall, winter, and spring (fig. 4). Seasonal water-level declines were between about 10 and $12 \mathrm{ft}$ in the FP3 wells, between about 6 and $7 \mathrm{ft}$ in the FP2 wells, and about $4 \mathrm{ft}$ in the FP1 and FP4 wells. 
Vertical and horizontal ground-water flow patterns were determined by converting water-level measurements from depth below land surface to depth above the North American Vertical Datum of 1988 (NAVD 88) to achieve comparability using a common reference datum. Vertical gradients were determined by comparing ground-water-level measurements at the three depths in each well nest. The vertically stratified water levels indicated that water generally flowed horizontally but had an upward flow component from the bottom to the middle and top of the sand at well nest FP3 and flowed horizontally (had little or no vertical gradient) at well nests FP4, FP2, and FP1. Beginning in July 2005, the upward gradient at well nest FP3 became steeper but otherwise showed little seasonal change (fig. 4). Minor downward and upward gradients also occurred at well nest FP2 during the summer of 2004 and summer of 2005, respectively.

Horizontal gradients indicated hydraulic-head gradients from well nest FP4 to well nest FP2 to well nest FP1, consistent with ground water flowing from the northwest towards well nest FP1 and the supply wells. Hydraulic heads at well nest FP3 also were generally higher than at well nest FP1, consistent with movement of ground water to the well field from the southwest (fig. 4). However, during the late summer of 2004, ground-water altitudes at well nest FP3 were only slightly higher than at well nest FP1, indicating very low hydraulic gradients. Such low gradients would be consistent with a lessening of the flow of ground water towards the well field from the southwest, perhaps as a result of seasonal shifts in ground-water recharge and irrigation pumping. During other periods, hydraulic-head differences between well nests FP3 and FP1 (higher hydraulic heads at well nest FP3) were similar to hydraulic-head differences between well nests FP2 and FP1; because the distances between these well-nest pairs are similar, the hydraulic-head differences indicate very similar horizontal hydraulic-head gradients towards the well field from the northwest and southwest.

\section{Ground-Water Age}

Concentrations of atmospheric trace gases and isotopic tracers dissolved in ground water were used to estimate the approximate time since the water entered the aquifer. Concentrations of three different chlorofluorocarbons (CFC-12, CFC-11, and CFC-113), sulfur hexafluoride ( $\left.\mathrm{SF}_{6}\right)$, and ratios of tritium $\left({ }^{3} \mathrm{H}\right)$ to the helium-3 $\left({ }^{3} \mathrm{He}\right)$ isotope derived from radioactive decay of ${ }^{3} \mathrm{H}$ were used to estimate the apparent recharge age of the ground-water sample. Because each agetracer technique has associated uncertainties and is affected in different ways by aquifer processes, ages estimated using these techniques are referred to as "apparent ages." The details of analytical and interpretative techniques used to estimate apparent ages are described by the U.S. Geological Survey (2005) and have been described previously for CFCs (Busenburg and Plummer, 1992), $\mathrm{SF}_{6}$ (Busenburg and Plummer, 2000), and
${ }^{3} \mathrm{H} /{ }^{3} \mathrm{He}$ (Schlosser and others, 1988, 1989; Solomon and others, 1992). Brief descriptions of the CFC, $\mathrm{SF}_{6}$ and ${ }^{3} \mathrm{H} /{ }^{3} \mathrm{He}$ methods are provided in Appendix 2.

Estimates of apparent ground-water age from tracer data were complicated by mixing of water of different ages in 10 of the 13 ground-water samples collected. In addition, the apparent ages indicated by $\mathrm{CFC}$ and $\mathrm{SF}_{6}$ methods often were older than those indicated by the ${ }^{3} \mathrm{H} /{ }^{3} \mathrm{He}$ method; this is probably because the depths from land surface to the water table of 75 to $95 \mathrm{ft}$ are large enough to cause $\mathrm{CFC}$ and $\mathrm{SF}_{6}$ apparent ages to lag behind ${ }^{3} \mathrm{H} /{ }^{3} \mathrm{He}$ apparent ages, as ${ }^{3} \mathrm{H} /{ }^{3} \mathrm{He}$ is not affected by time for atmospheric gases to reach the bottom of deep unsaturated zones. Finally, geologic sources of ${ }^{3} \mathrm{He}$ and $\mathrm{SF}_{6}$ in some ground water apparently affected ${ }^{3} \mathrm{H} /{ }^{3} \mathrm{He}$ and $\mathrm{SF}_{6}$ estimates. The effect of these geologic sources was to add uncertainty to age estimates compared to ideal conditions. Summary estimates of ground-water ages and mixtures are reported in the following paragraphs. Additional details of the estimates are discussed in Appendix 2.

Multiple interpretations of concentrations of atmospheric tracers to estimate ground-water ages are possible using different models or approximations of how ground water recharged during a particular year moves and mixes with water of other ages. Comparisons of tracer concentrations to expected historical values in recharge and comparisons of different tracers indicate whether or not substantial mixing of water of different ages occurs. Estimates of ground-water age from environmental tracer data may be relatively straightforward for a water sample with a single age; estimation is more complex for a sample that is a mixture of water of varying ages (Cook and Böhlke, 2000). A mixture can be the result of convergence of ground-water flow to a pumping well, for example, or it can be an artifact of sampling a well with a long screen that intersects water of variable age.

On the basis of different tracer concentrations plotted in relation to each other in comparison with curves predicted with different mixing models (see Appendix 2), it was interpreted that the samples collected were a mixture of relatively young water containing modern atmospheric tracers and relatively old water that did not contain modern atmospheric tracers. Although alternative mixing scenarios are possible, it is not possible to quantify more complex mixing of more than two bodies of water of different age with the data collected for the study.

Best estimates of apparent recharge dates of unmixed ground-water samples or mean age of young-water fractions in samples collected from monitoring wells ranged from 1985 to 2002 (figs. 5 and 6, table 1). For monitoring-well samples containing mixed-aged water, best estimates of the fraction of the sample consisting of young water ranged from 26 to 77 percent. Best estimates of apparent mean recharge dates of young-water fractions in samples collected from four supply wells in the Seward west well field ranged from about 1980 to 1990. The best estimate of the fraction of the supply-well samples consisting of young water ranged from 39 to 54 percent. It is implicit in the mixing calculations that the remainder 

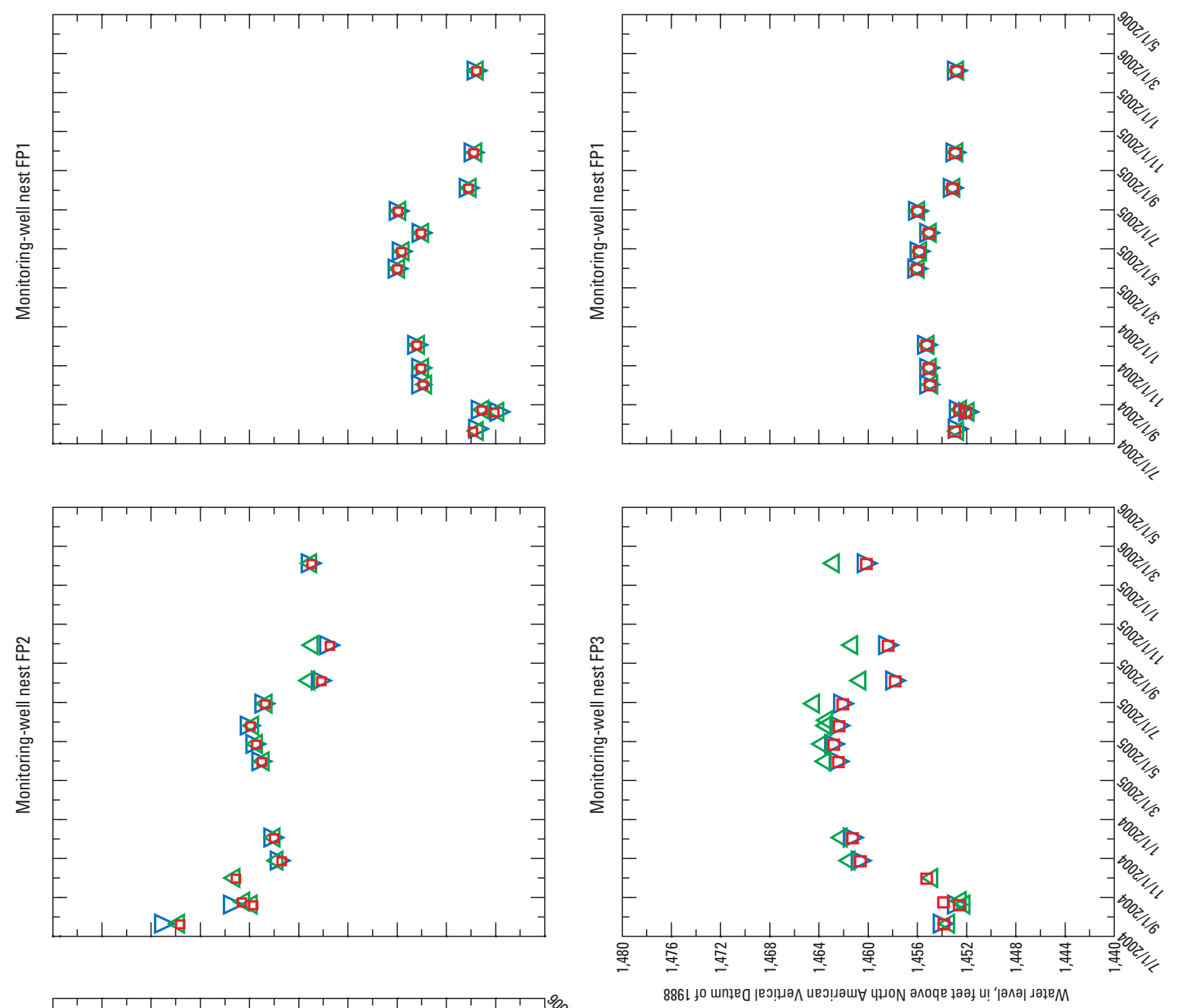

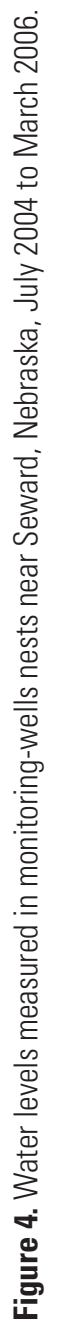
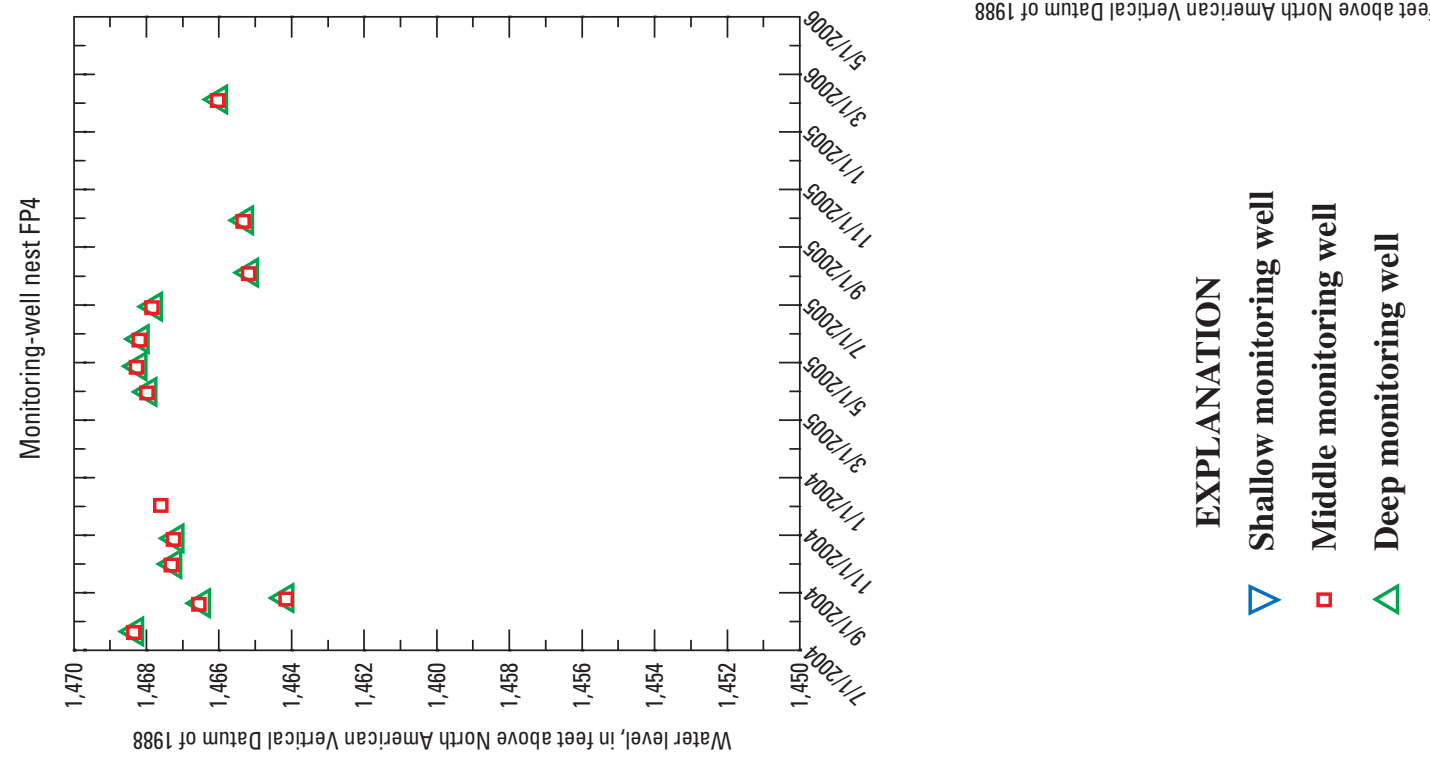

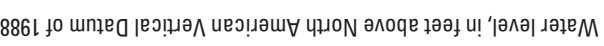




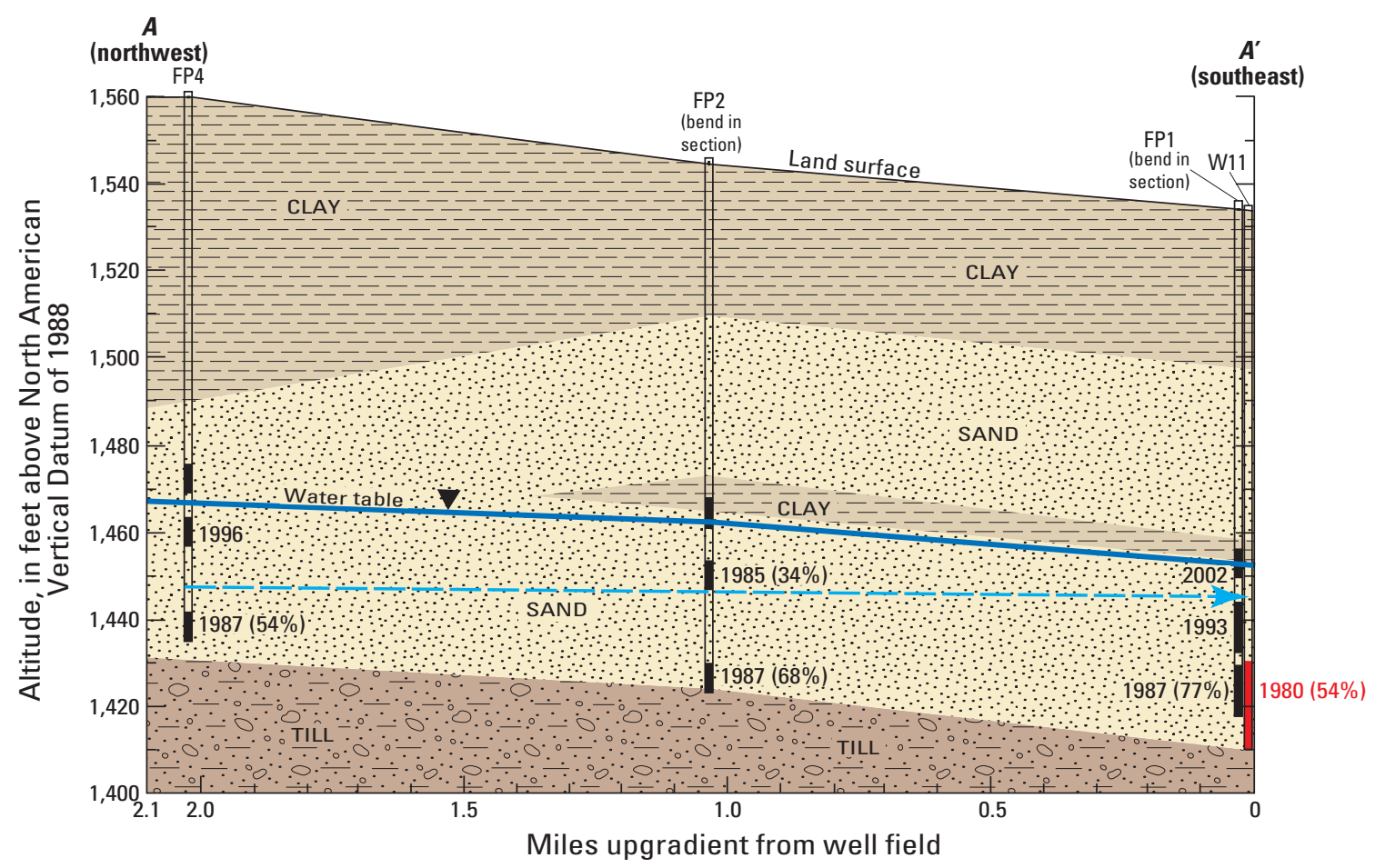

\section{EXPLANATION}

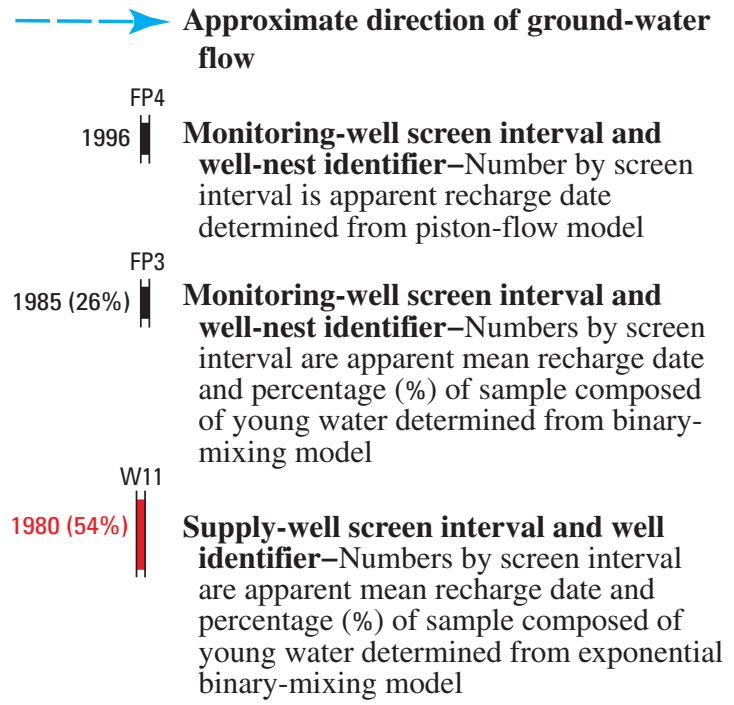

Trace of sections shown in figure 1

Vertical scale greatly exaggerated

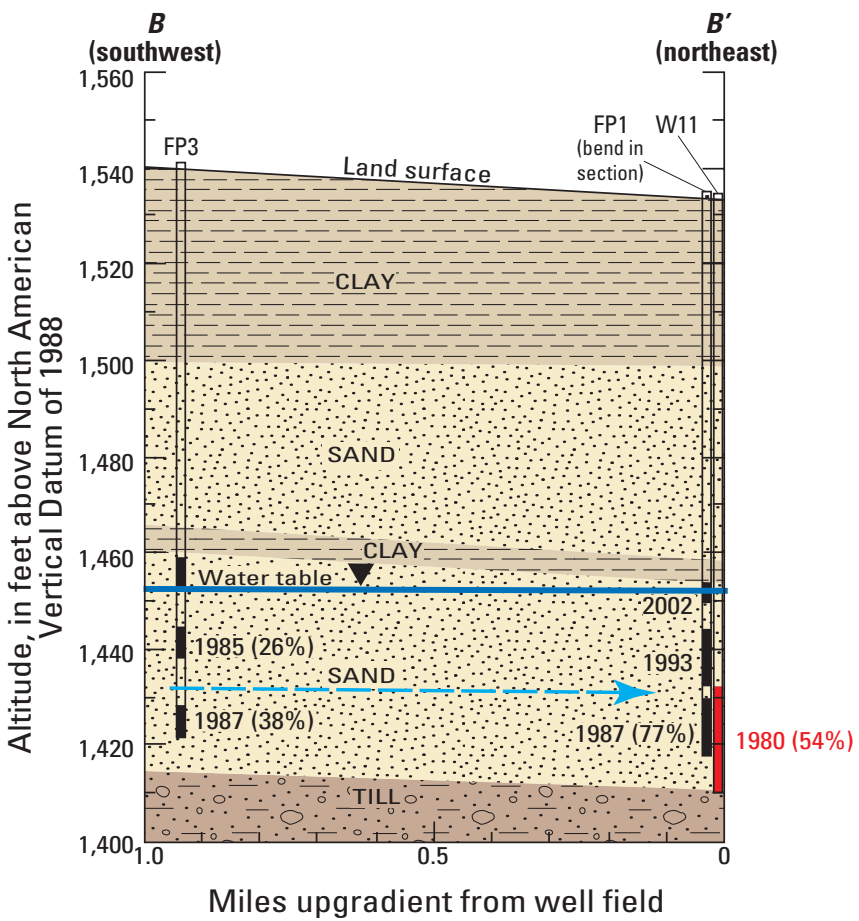

Figure 5. Best estimate of apparent mean recharge date and percentage of sample composed of young water (less than 60 years old) for ground-water samples collected near Seward, Nebraska, 2003-04. 

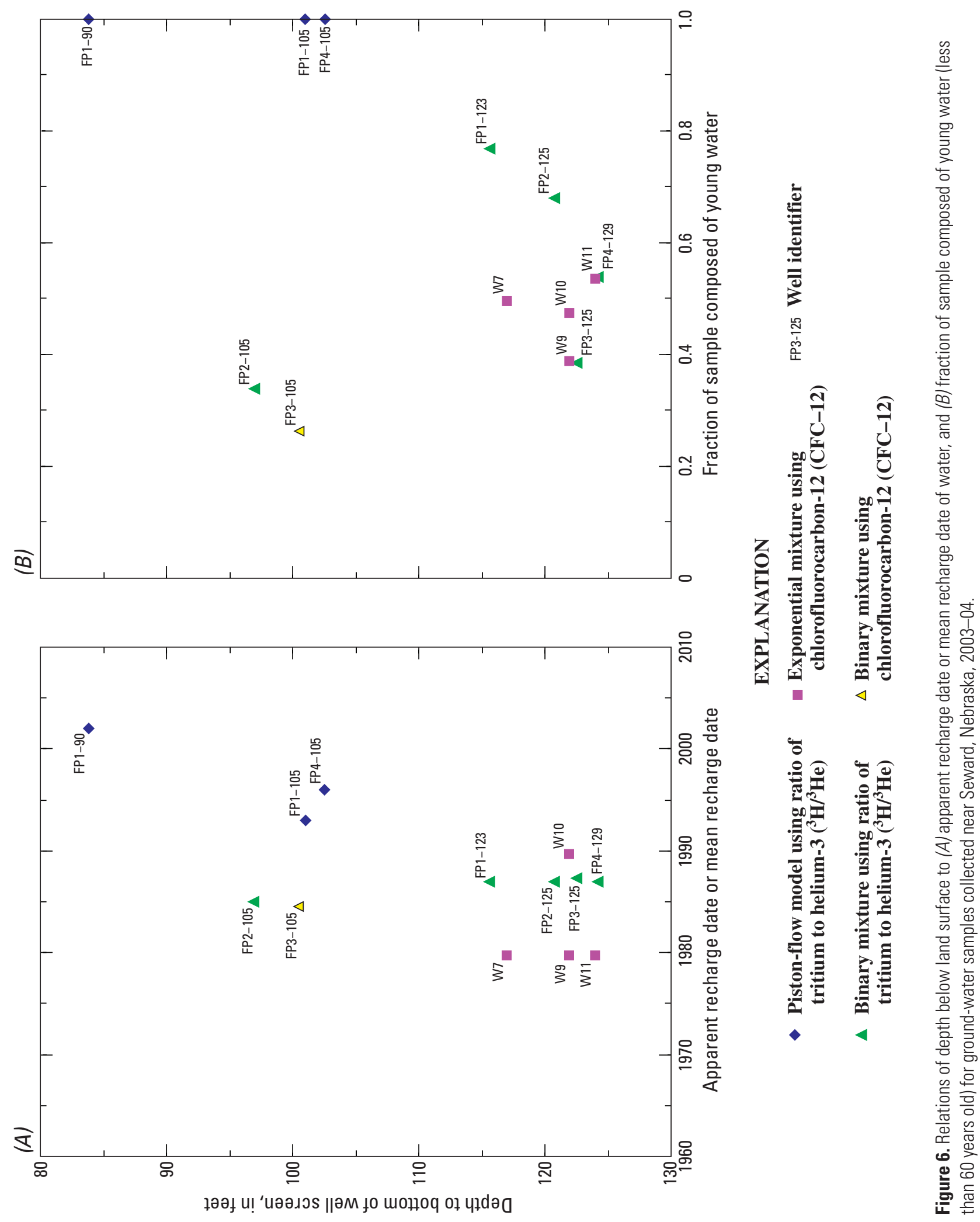





of the sample that is not young water consists of water that is more than 60 years old and contains no detectable quantities of modern atmospheric tracers. This "old" water accounted for 23 to 74 percent of water in the samples.

Ground-water ages and mixing fractions were estimated primarily on the basis of $\mathrm{CFC}-12$ and ${ }^{3} \mathrm{H} /{ }^{3} \mathrm{He}$ data (table 1 ). The three CFC tracers (CFC-12, CFC-11, and CFC-113) generally indicated very similar ages and mixing fractions. Of the three CFC tracers, CFC-12 is the least susceptible to sorption and degradation, although in the case of this study, these processes did not appear to affect CFC concentrations. Therefore, only ages estimated from CFC-12 data are reported here. The ${ }^{3} \mathrm{H} /{ }^{3} \mathrm{He}$ method also was used as a primary dating technique. There were consistent differences between the $\mathrm{CFC}-12$ and ${ }^{3} \mathrm{H} /{ }^{3} \mathrm{He}$ tracer methods. Apparent ground-water ages estimated using the ${ }^{3} \mathrm{H} /{ }^{3} \mathrm{He}$ method were as much as 20 years younger than those estimated using the $\mathrm{CFC}-12$ method with an average difference of 9 years (see Appendix 2). The differences between these methods probably occur because the relatively thick unsaturated zone ( 75 to $96 \mathrm{ft}$ ) of the High Plains aquifer in the study area causes CFC-12 concentrations in soil gas at the bottom of the unsaturated zone to lag several years behind atmospheric CFC-12 concentrations. Consequently, CFC-12 ages are older than true ages or ages estimated using the ${ }^{3} \mathrm{H} /{ }^{3} \mathrm{He}$ tracer method, which is not affected by unsaturated-zone lag times. For two monitoring wells (FP2-105 and FP3-105), ${ }^{3} \mathrm{H} /{ }^{3} \mathrm{He}$ sampling results were anomalous. For well FP3-105, the mean age and fraction of young water in the sample could not be estimated. For well FP2-105, apparent mean age was older, and the fraction of young water in the sample was less than that for other samples at comparable depths. For these two samples, estimates were based on results using the CFC-12 method instead. For the four supply wells sampled in November $2003,{ }^{3} \mathrm{H} /{ }^{3} \mathrm{He}$ samples were not collected. Therefore, estimates were based solely on results from the CFC-12 method. The differences between CFC-12 and ${ }^{3} \mathrm{H} /{ }^{3} \mathrm{He}$ ages were greater for relatively shallow water samples and did not occur for all samples (Appendix 2). Therefore, in the wells screened in the middle to lower part of the aquifer where ages were based on $\mathrm{CFC}-12$ results, the ages were not adjusted to compensate for the fact that $\mathrm{CFC}-12$ ages may be older than ages determined using the ${ }^{3} \mathrm{H} /{ }^{\beta} \mathrm{He}$ method.

At three of the nine monitoring wells sampled, groundwater ages were estimated using a piston-flow model (PFM), which is based on the concept that ground water that recharges during a particular year does not mix with water of other ages along the flow path to the sampled well. The relatively shallow ground-water samples from wells FP1-90, FP1-105, and FP4-105 may have not been subjected to as much mixing as deeper samples because most irrigation and supply wells are screened near the bottom of the aquifer. Samples from the shallowest well (FP1-90), with the water table within the screened interval, had an apparent recharge date of 2002 $\left({ }^{3} \mathrm{H} /{ }^{3} \mathrm{He}\right.$ method) (table 1, fig. 5). Samples collected from the upper-to-middle part of the aquifer at wells FP1-105 and FP4-105 had PFM apparent recharge dates of 1993 and 1996, respectively, indicating traveltimes from the recharge area to the well at the time of sampling of 8 to 11 years (table 1, fig. $6 A)$.

In six of the nine monitoring wells sampled, discrepancies between tracers, specifically the comparison of CFC-12 or ${ }^{3} \mathrm{H} /{ }^{3} \mathrm{He}$ results to ${ }^{3} \mathrm{H}$, indicated that water from the wells consists of a mixture of water of different ages (see Appendix 2 for selected tracer-tracer plots, figs. 2-1-2-3). Some of the samples collected from intermediate depths and all of the samples collected from the lower parts of the aquifer contained mixed water (fig. 6B). Apparent mean recharge dates of young-water fractions of these mixed samples (referring to monitoring wells) were all in the mid-1980s, indicating traveltimes of 17 to 19 years from the recharge area to the monitoring well at the time of sampling for the mean youngwater fraction (table 1). Because this water is mixed, it also contains "old" water more than 60 years old. In addition, the supply wells appear to represent a mixture of two water types: (1) exponentially mixed young water with a mean age of 13 to 23 years, and (2) "old" water. Such mixing is not surprising considering that the High Plains aquifer is relatively thin $(50 \mathrm{ft})$ in the area of the supply wells and has a relatively high density of wells (4.75 irrigation wells per square mile plus supply wells), indicating that withdrawals are relatively large. Such pumping stress has the effect of increasing ground-water velocities and mixing of ground water. Although alternative mixing models can be used to interpret the results, the mean ages and mixing fractions for the primary mixing models used were similar. Results from multiple models are presented in table 1 for comparison.

All of the samples collected contained at least some water that recharged the aquifer in the last 25 years. Relations of ground-water recharge dates or mean recharge dates of water mixtures with depth were not consistent (fig. 6A). In well nests FP1 and FP4, changes in mean recharge dates from the shallowest to the deepest sample were 15 and 9 years, respectively. However, mean recharge dates in the deepest wells at the FP2 and FP3 well nests were slightly younger and very similar to recharge dates in the shallowest wells (fig. 5). In these well nests, the fractions of young water in the sample also were less in the shallow samples than in the deep wells (fig. 6B). The occurrence of more young water in the deep rather than intermediate parts of the aquifer at these locations is consistent with the effects of pumping from irrigation and supply wells, which are screened primarily at the bottom or throughout the entire aquifer. Withdrawals from the lower part of the aquifer have the effect of drawing younger water from shallower depths to the deeper part of the aquifer, perhaps leaving less young ground water at intermediate depths away from the depths of supply-well screens.

Horizontally, water age along estimated ground-water flow paths did not follow a clear pattern of younger to older with distance along the flow path towards the supply wells. Such a horizontal pattern is common in relatively simple ground-water systems without a large amount of mixing of different-aged water. The complex pattern of water age probably 
is affected at least partially by pumping in the aquifer. Consequently, in most cases, meaningful horizontal traveltimes from upgradient wells to wells farther downgradient (near the supply wells) could not be calculated or were so small as to be questionable. Probably the most reliable estimate of horizontal traveltimes can be calculated from comparison of the mean recharge date at monitoring well FP4-105 (1996) to well FP1-123 (1987). The difference in age implies that ground water, were it to flow along a path between these two wells, would take an average of 9 years to travel this distance. Although hydraulic heads indicate such a ground-water flow path is conceptually reasonable, the presence of older water in between these wells at well nest FP2 and the likely complexity of ground-water flow due to a highly pumped system suggest that it is not certain that these two wells are along a true ground-water flow path. These uncertainties need to be considered when using the apparent 9-year traveltime as an estimate of horizontal traveltime. However, the general similarity of water ages at similar depths between different well nests is consistent with the fact that horizontal flow in the aquifer is relatively rapid. These results indicate that traveltimes in the study area may be much less than the 30-year traveltime estimated from simple analytical modeling to delineate wellhead protection areas.

\section{Ground-Water Quality}

Concentrations of constituents were compared with U.S. Environmental Protection Agency (USEPA) drinking-water standards (U.S. Environmental Protection Agency, 2004) to place the quality of the untreated supply- and monitoring-well water in the context of nationally recognized public-supply criteria. Regular testing is conducted by public-water suppliers to ensure that drinking-water standards are not exceeded. If needed, the water is treated to reduce contaminant concentrations to levels that are safe for human consumption, or well usage is discontinued. Concentrations in this report are untreated ground water and, therefore, do not reflect water quality delivered to consumers; drinking-water standards do not apply to untreated ground water. Comparisons of concentrations in ground-water samples to drinking-water standards are made only to illustrate ground-water quality relative to established drinking-water benchmarks.

USEPA has established several kinds of drinking-water standards (U.S. Environmental Protection Agency, 2004). The Maximum Contaminant Level (MCL) is the highest level of a contaminant that is allowed in publicly supplied drinking water. The Secondary Drinking-Water Regulation (SDWR) is a nonenforceable guideline regarding cosmetic or esthetic effects of drinking water. The treatment technique (TT) specifies a constituent concentration above which a public water supplier is required to physically remove the constituent from delivered water.
Analytical results from water samples collected from the four supply wells in the study area in November 2003 indicated that water quality was generally suitable for drinking with regard to major ions, trace elements, and pesticide compounds (table 2). However, nitrite plus nitrate as nitrogen concentrations in water from all four supply wells were larger than the USEPA MCL of $10 \mathrm{mg} / \mathrm{L}$, ranging from 11.3 to $13.5 \mathrm{mg} / \mathrm{L}$. Nitrite as nitrogen concentrations were less than the laboratory reporting level of $0.008 \mathrm{mg} / \mathrm{L}$; therefore, nitrate plus nitrite as nitrogen concentrations are referred to as nitrate concentrations in this report. Dissolved-solids concentrations in water from three of the four wells also exceeded USEPA nonenforceable SDWR of $500 \mathrm{mg} / \mathrm{L}$. Five pesticides or pesticide degradation products were detected in the supply wells at concentrations much smaller than the maximum concentration allowed by USEPA drinking-water regulations. Most pesticide compound detections were reported as estimated by the laboratory. Although the compounds were positively identified, concentrations were estimated when the concentration was less than the laboratory reporting level, less than the lowest calibration standard, uncertain because of a matrix interference, or because the compound was detected in instrument blanks (Childress and others, 1999). Deethylatrazine, a degradation product of the herbicide atrazine, was always reported as an estimated value because the analytical method does not meet method performance criteria (Zaugg and others, 1995). The pesticide compound with the largest concentrations was atrazine and was detected in water from all four wells in the west well field at concentrations ranging from 0.103 to $0.346 \mu \mathrm{g} / \mathrm{L}$.

Complete tables of the analytical results from monitoring-well water samples are published in Hitch and others (2005). The relative proportions of cations and anions in water samples collected from the nine monitoring wells in the study area exhibited patterns related to depth and position along flow paths. When elements dissolve in water, they dissociate into either positively charged ions (cations) or negatively charged ions (anions). Major cations in ground water typically are calcium, magnesium, sodium, and potassium. Major anions in ground water typically are carbonate alkalinity [reported as calcium carbonate $\left(\mathrm{CaCO}_{3}\right)$ equivalent], sulfate, chloride, and fluoride. When nitrate is present in large quantities, it also can be a major anion. The total electrical charge (or milliequivalents) of all cations and anions in a solution must balance to maintain electrical neutrality. One way to represent the relative percentage of the major ions in water is to plot them on a trilinear diagram. The relative proportions of ions as a function of areal position and depth below land surface are shown in figure 7. A shift in anion position indicates that the relative amount of carbonate alkalinity decreases and the relative amount of sulfate increases as water moves along the groundwater flow paths (fig. 7A). A shift in cations with depth below land surface indicates that the relative amount of calcium decreases and the relative amount of sodium increases from deep to shallow wells (fig. $7 B$ ). 
Table 2. Physical properties and concentrations of selected inorganic constituents and detected pesticide compounds in untreated ground water collected from supply wells near Seward, Nebraska, November 2003.

[Constituents are from filtered samples and represent dissolved phase. USEPA, U.S. Environmental Protection Agency; NTU, nephelometric turbidity unit; TT, treatment technique; mg/L, milligrams per liter (parts per million); SDWR, Secondary Drinking-Water Regulations; $\mu$ S/cm, microsiemens per centimeter; ${ }^{\circ} \mathrm{C}$, degrees Celsius; MCL, Maximum Contaminant Level; N, nitrogen; <, less than; $\mu \mathrm{g} / \mathrm{L}$, micrograms per liter (parts per billion); E, estimated; --, not applicable]

\begin{tabular}{|c|c|c|c|c|c|}
\hline \multirow{2}{*}{ Constituent or property } & \multicolumn{4}{|c|}{ Supply well (fig. 1) } & \multirow{2}{*}{$\begin{array}{l}\text { USEPA drinking-water standard / type of } \\
\text { standard' }\end{array}$} \\
\hline & W7 & W9 & W10 & W11 & \\
\hline \multicolumn{6}{|c|}{ Physical properties } \\
\hline Specific conductance, in $\mu \mathrm{S} / \mathrm{cm}$ at $25{ }^{\circ} \mathrm{C}$ & 799 & 892 & 730 & 837 & -- \\
\hline $\mathrm{pH}$, in standard units & 6.8 & 6.8 & 6.9 & 6.8 & 6.5-8.5 / SDWR \\
\hline Turbidity, in NTU & .1 & .2 & .2 & .1 & $5 / \mathrm{TT}$ \\
\hline Oxygen, in mg/L & 6.4 & 4.9 & 6.5 & 5.5 & -- \\
\hline \multicolumn{6}{|c|}{ Selected inorganic constituents } \\
\hline Dissolved solids, in $\mathrm{mg} / \mathrm{L}$ & 517 & 559 & 462 & 541 & 500 / SDWR \\
\hline Sulfate, in $\mathrm{mg} / \mathrm{L}$ & 110 & 149 & 67.1 & 127 & 250 / SDWR \\
\hline Nitrite plus nitrate as $\mathrm{N}$, in $\mathrm{mg} / \mathrm{L}$ & 12.8 & 11.3 & 12.7 & 13.5 & $10 / \mathrm{MCL}$ \\
\hline Arsenic, in $\mu \mathrm{g} / \mathrm{L}$ & 3.5 & 3.9 & 5.9 & 4.8 & $10 / \mathrm{MCL}$ \\
\hline Uranium, in $\mu \mathrm{g} / \mathrm{L}$ & 8.42 & 9.58 & 8.00 & 7.16 & $30 / \mathrm{MCL}$ \\
\hline \multicolumn{6}{|c|}{ Pesticide compounds detected } \\
\hline Alachlor, in $\mu \mathrm{g} / \mathrm{L}$ & $<.005$ & $<.005$ & $<.005$ & E.003 & $2 / \mathrm{MCL}$ \\
\hline Atrazine, in $\mu \mathrm{g} / \mathrm{L}$ & .242 & .148 & .103 & .346 & $3 / \mathrm{MCL}$ \\
\hline Deethylatrazine $^{2}$, in $\mu \mathrm{g} / \mathrm{L}$ & E.027 & E.016 & E.129 & E. 225 & -- \\
\hline Metolachlor, in $\mu \mathrm{g} / \mathrm{L}$ & E.006 & $<.013$ & $<.013$ & E.007 & $100 / \mathrm{MCL}$ \\
\hline
\end{tabular}

${ }^{1}$ U.S. Environmental Protection Agency, 2004.

${ }^{2} \mathrm{~A}$ degradation product of atrazine.

It is unlikely that nitrate concentrations in the aquifer near the Seward west well field are reduced by denitrification in the aquifer because oxic geochemical conditions do not favor the occurrence of this reaction. Denitrification can naturally reduce nitrate concentrations in aquifers. In the process of denitrification bacteria consume nitrate as an energy source, converting it to inert nitrogen gas through a series of reactions. Denitrification generally will occur in anaerobic conditions; therefore, dissolved oxygen concentrations can indicate whether denitrification is likely to be an important factor. Dissolved oxygen concentrations less than $1 \mathrm{mg} / \mathrm{L}$ generally are associated with conditions favorable for denitrification (Trevors, 1985).

Dissolved oxygen concentrations in all ground-water samples collected during this study indicated that denitrification probably is not an important factor near the Seward well field; dissolved oxygen concentrations in samples ranged from 4.9 to $6.5 \mathrm{mg} / \mathrm{L}$ in supply wells (table 2 ) and from 4.4 to $8.1 \mathrm{mg} / \mathrm{L}$ in monitoring wells (table 3 ). Because a product of denitrification is nitrogen gas, quantities of nitrogen gas present in ground-water samples at levels in excess of those expected in water in equilibrium with the atmosphere also can indicate that denitrification is occurring. However, groundwater samples collected as part of this study did not contain excess nitrogen gas (Appendix 2, table 5).

Nitrate and dissolved-solids concentrations typically are related to depth below the water table. However, neither was consistently related to depth in this study. At monitoringwell nests FP3 and FP4, nitrate concentrations were largest near the water table. Elsewhere, nitrate concentration was largest in the deeper well of nest FP2 (well FP2-125) and largest at the intermediate depth of nest FP1 (well FP1-105) (fig. 8). Dissolved-solids concentrations exhibited the same patterns as nitrate concentrations (fig. 9). Concentrations 

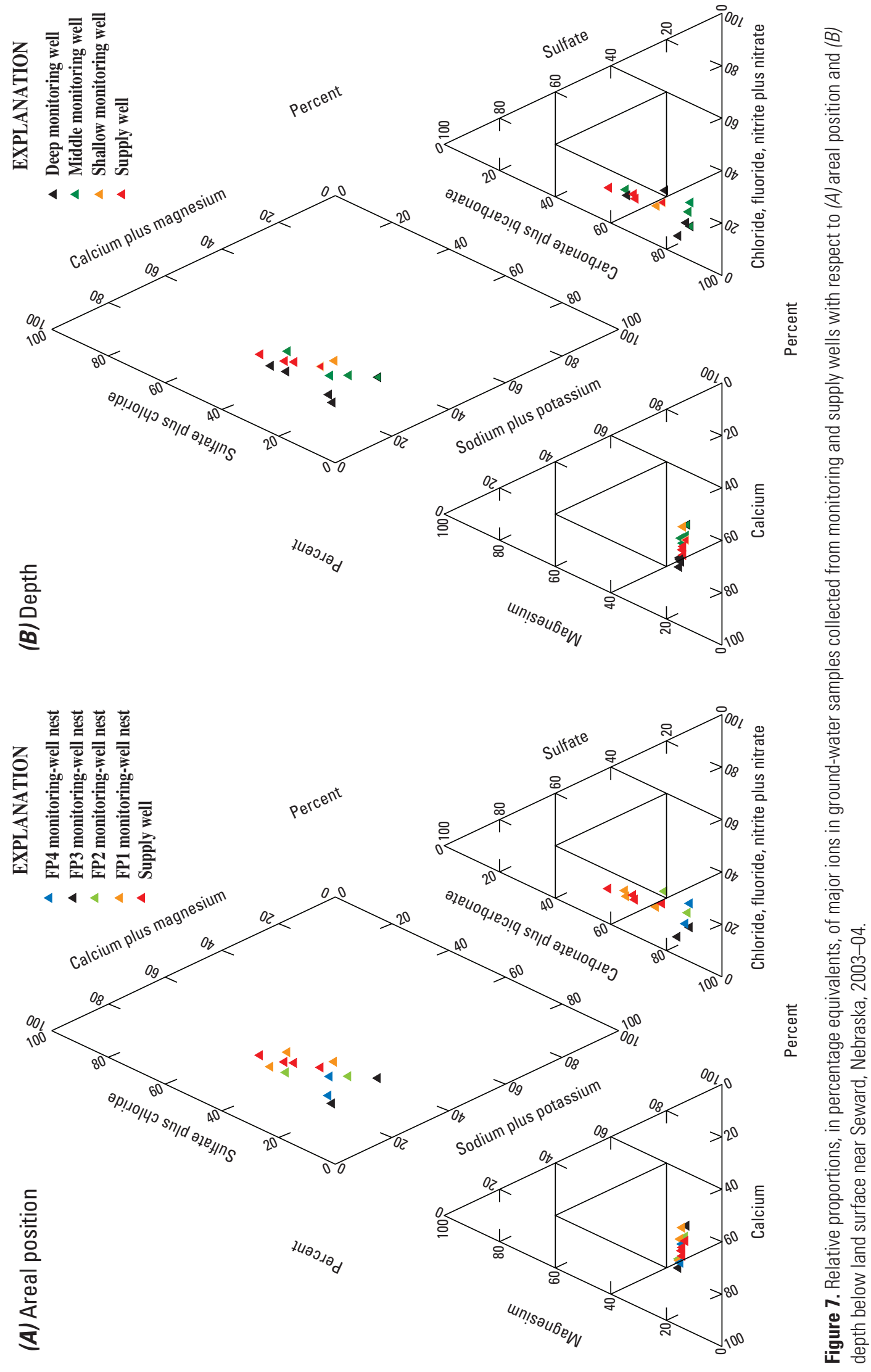
Table 3. Physical properties and concentrations of selected inorganic constituents in ground-water samples collected from monitoring wells near Seward, Nebraska, August 2004.

[Constituents are dissolved. USEPA, U.S. Environmental Protection Agency; NTU, nephelometric turbidity unit; >, TT, treatment technique; mg/L, milligrams per liter (parts per million); SDWR, Secondary Drinking-Water Regulations; $\mu \mathrm{S} / \mathrm{cm}$, microsiemens per centimeter; ${ }^{\circ} \mathrm{C}$, degrees Celsius; MCL, Maximum Contaminant Level; <, less than; $\mu \mathrm{g} / \mathrm{L}$, micrograms per liter (parts per billion); E, estimated; --, not applicable]

\begin{tabular}{|c|c|c|c|c|c|c|c|c|c|c|}
\hline \multirow{3}{*}{$\begin{array}{l}\text { Constituent or } \\
\text { property }\end{array}$} & \multicolumn{9}{|c|}{ Monitoring-well nest } & \multirow{3}{*}{$\begin{array}{l}\text { USEPA drinking- } \\
\text { water standard / } \\
\text { type of standard' }\end{array}$} \\
\hline & \multicolumn{3}{|c|}{ FP1 well nest } & \multicolumn{2}{|c|}{ FP2 well nest } & \multicolumn{2}{|c|}{ FP3 well nest } & \multicolumn{2}{|c|}{ FP4 well nest } & \\
\hline & $\begin{array}{l}\text { FP1-90 } \\
\text { (shal- } \\
\text { low) }\end{array}$ & $\begin{array}{l}\text { FP1-105 } \\
\text { (middle) }\end{array}$ & $\begin{array}{l}\text { FP1-123 } \\
\text { (deep) }\end{array}$ & $\begin{array}{l}\text { FP2-105 } \\
\text { (middle) }\end{array}$ & $\begin{array}{l}\text { FP2-125 } \\
\text { (deep) }\end{array}$ & $\begin{array}{l}\text { FP3-105 } \\
\text { (middle) }\end{array}$ & $\begin{array}{l}\text { FP3-125 } \\
\text { (deep) }\end{array}$ & $\begin{array}{l}\text { FP4-105 } \\
\text { (middle) }\end{array}$ & $\begin{array}{l}\text { FP4-129 } \\
\text { (deep) }\end{array}$ & \\
\hline \multicolumn{11}{|c|}{ Physical properties } \\
\hline $\begin{array}{l}\text { Water level, in } \\
\text { feet below } \\
\text { land surface }\end{array}$ & 81.59 & 81.69 & 81.68 & 85.39 & 85.32 & 88.32 & 89.34 & 95.67 & 95.64 & -- \\
\hline $\begin{array}{l}\text { Specific con- } \\
\text { ductance, } \\
\text { in } \mu \mathrm{S} / \mathrm{cm} \text { at } \\
25^{\circ} \mathrm{C}\end{array}$ & 589 & 820 & 768 & 594 & 657 & 617 & 556 & 643 & 568 & -- \\
\hline $\begin{array}{l}\mathrm{pH} \text {, in standard } \\
\text { units }\end{array}$ & 6.5 & 6.7 & 6.7 & 6.8 & 6.8 & 6.9 & 6.7 & 6.8 & 7.0 & 6.5-8.5 / SDWR \\
\hline $\begin{array}{l}\text { Temperature, } \\
\text { in }{ }^{\circ} \mathrm{C}\end{array}$ & 15.2 & 15.0 & 14.2 & 14.1 & 15.2 & 16.3 & 14.3 & 14.7 & 14.6 & -- \\
\hline $\begin{array}{l}\text { Turbidity, in } \\
\text { NTU }\end{array}$ & 1.2 & 1.5 & 3.3 & .9 & 1.3 & .3 & .3 & .3 & .6 & $5 / \mathrm{TT}$ \\
\hline $\begin{array}{c}\text { Oxygen, in } \\
\mathrm{mg} / \mathrm{L}\end{array}$ & 5.8 & 7.0 & 4.8 & 7.9 & 4.4 & 5.6 & 5.0 & 8.1 & 5.9 & -- \\
\hline \multicolumn{11}{|c|}{ Selected inorganic constituents } \\
\hline $\begin{array}{l}\text { Dissolved sol- } \\
\text { ids, in mg/L }\end{array}$ & 386 & 553 & 531 & 383 & 435 & 389 & 354 & 427 & 377 & $500 /$ SDWR \\
\hline $\begin{array}{l}\text { Sulfate, in } \\
\mathrm{mg} / \mathrm{L}\end{array}$ & 60.9 & 129 & 119 & 31.2 & 58.5 & 30.4 & 39.0 & 32.2 & 32.1 & 250 / SDWR \\
\hline $\begin{array}{l}\text { Chloride, in } \\
\mathrm{mg} / \mathrm{L}\end{array}$ & 4.84 & 4.96 & 4.81 & 5.53 & 10.5 & 3.36 & 3.20 & 2.87 & 4.21 & 250 / SDWR \\
\hline $\begin{array}{l}\text { Fluoride, in } \\
\mathrm{mg} / \mathrm{L}\end{array}$ & .3 & .3 & .3 & .3 & .2 & .3 & .3 & .3 & .3 & 4 / MCL \\
\hline $\begin{array}{l}\text { Nitrite as } \mathrm{N} \text {, in } \\
\mathrm{mg} / \mathrm{L}\end{array}$ & $<.008$ & $<.008$ & $<.008$ & $<.008$ & $<.008$ & $<.008$ & $<.008$ & $<.008$ & $<.008$ & -- \\
\hline $\begin{array}{l}\text { Nitrite plus } \\
\text { nitrate as } \mathrm{N} \text {, } \\
\text { in } \mathrm{mg} / \mathrm{L}\end{array}$ & 8.96 & 14.5 & 11.6 & 11.1 & 14.0 & 8.48 & 3.68 & 16.7 & 7.83 & $10 / \mathrm{MCL}$ \\
\hline
\end{tabular}

${ }^{1}$ U.S. Environmental Protection Agency (2004).

of nitrate, dissolved solids, and some major ions in water sampled from supply well W11 were intermediate between concentrations in the deep- and medium-depth monitoring wells at well nest FP1. These results are consistent with water from well W11 being a mixture of water from deep- and medium-depth parts of the saturated sand layer.

Nitrate concentrations coupled with apparent recharge dates can be used to reconstruct historical trends in groundwater nitrate concentrations (Böhlke, 2002). These interpreted nitrate trends then can be used to examine relations between historical land-use practices such as fertilizer applications and nitrate in ground water. Measured nitrate concentrations corresponding to the estimated sample age or mean age of the young-water fraction in mixed samples are shown in figure 10. Relations of measured nitrate concentrations corresponding to estimated recharge ages and historical fertilizer applications are not evident. However, if the ground-water samples are mixtures of young water and old water, the measured nitrate 


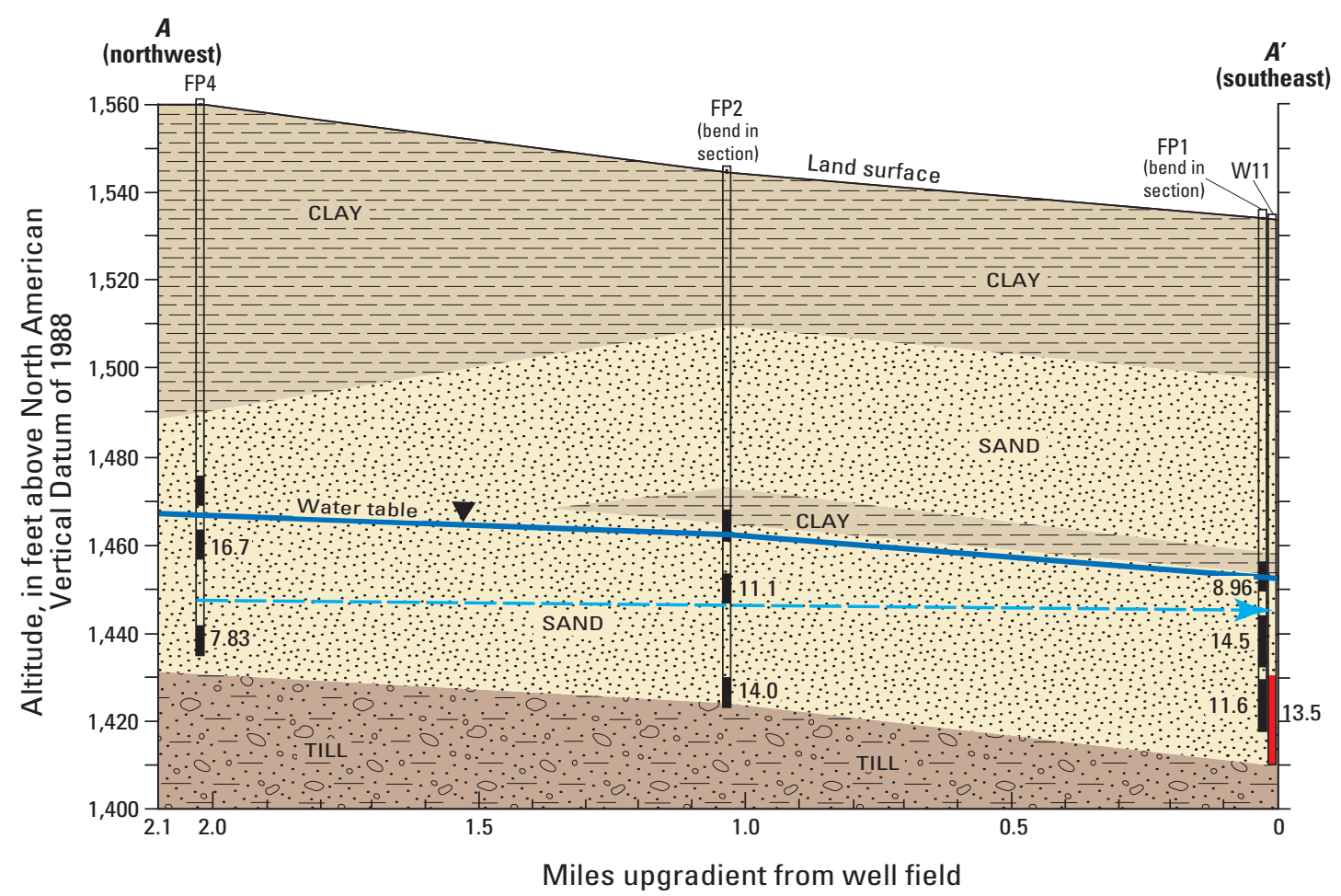

\section{EXPLANATION}

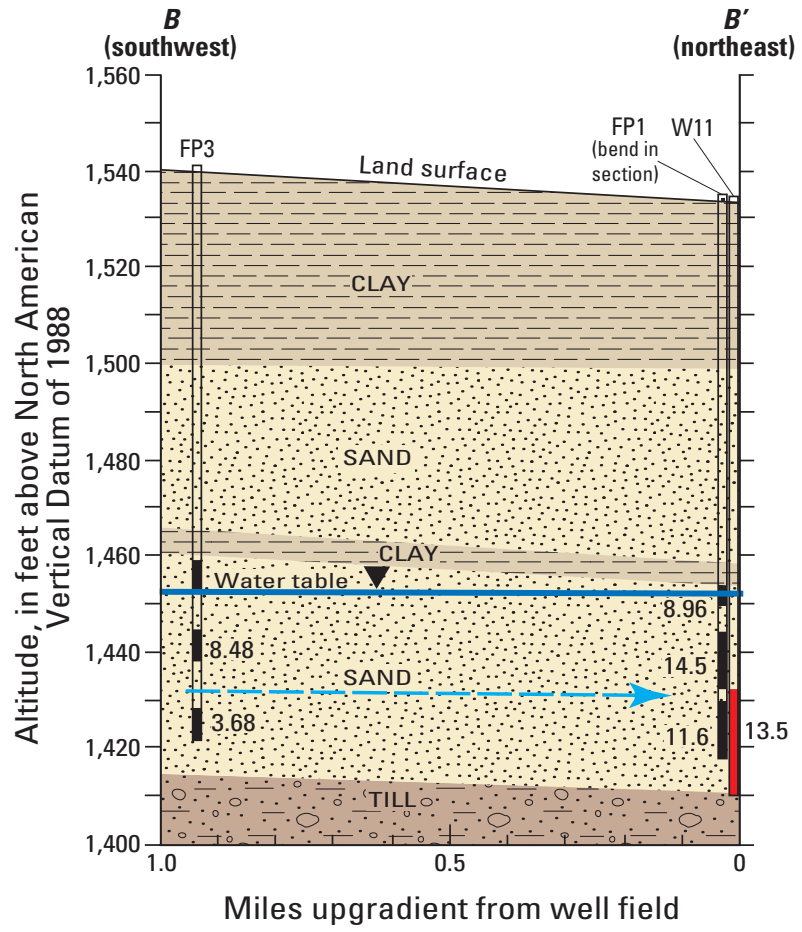

Figure 8. Nitrate concentrations in ground-water samples collected from monitoring wells near Seward, Nebraska, August 2004, and supply well W11, November 2003. 


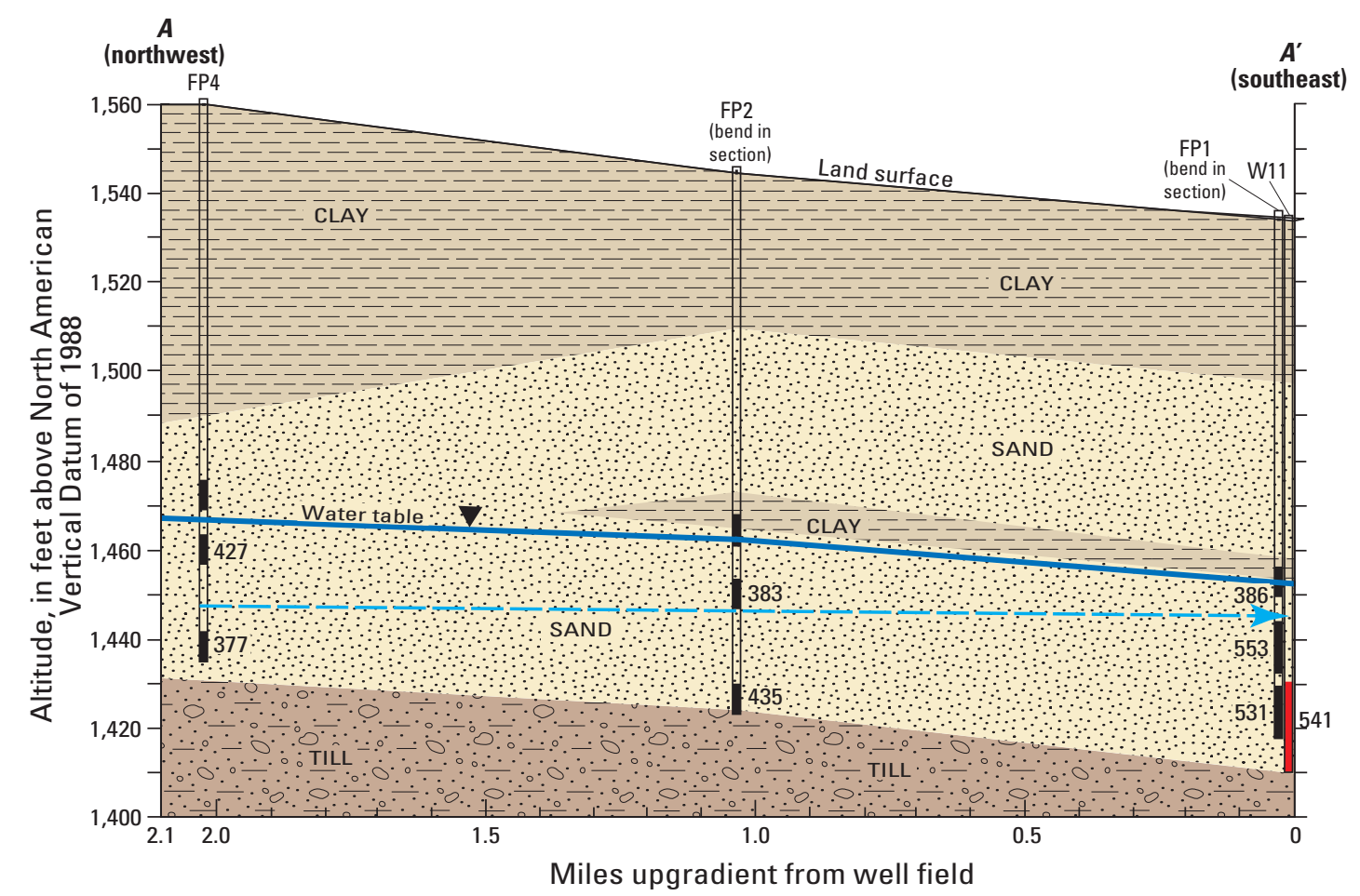

\section{EXPLANATION}

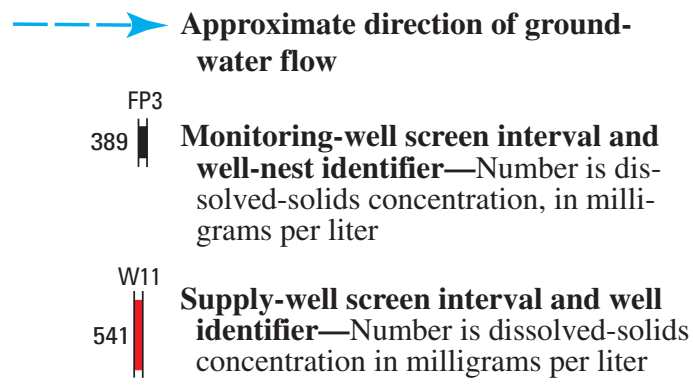

Trace of sections shown in figure 1

Vertical scale greatly exaggerated

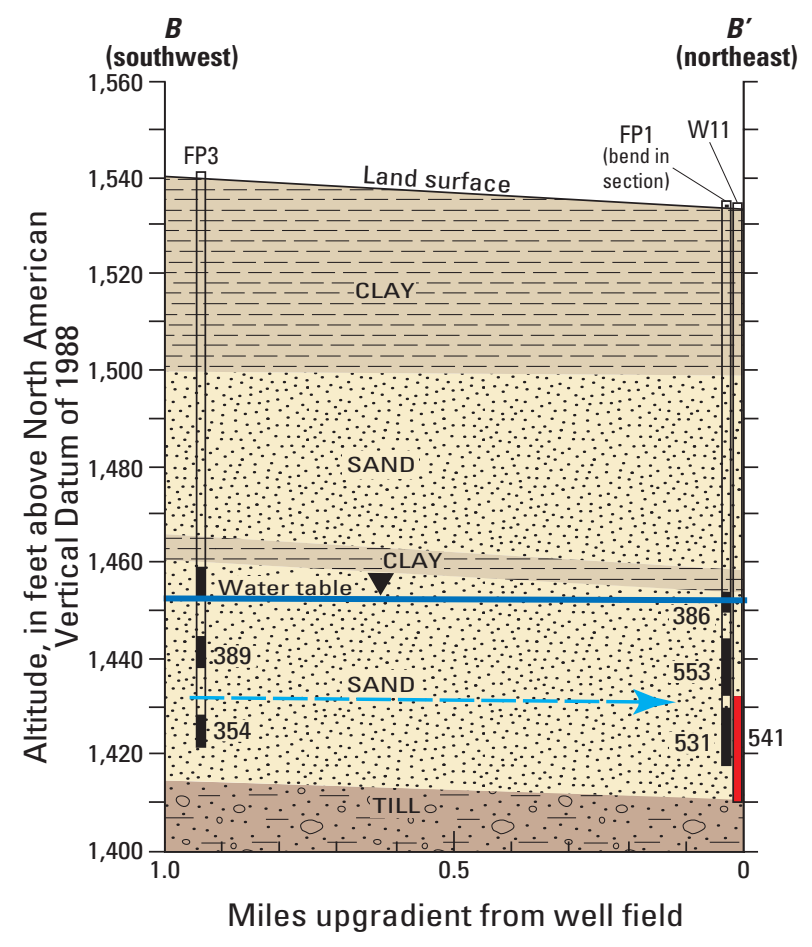

Figure 9. Dissolved-solids concentrations in ground-water samples collected from monitoring wells near Seward, Nebraska, August 2004, and supply well W11, November 2003.

concentrations should reflect this mixing as well. Mixedsample nitrate values should reflect mixing of young water containing nitrate with old water containing little or no nitrate. Ground water that entered the aquifer more than 60 years ago (that is, "old" water) should have smaller nitrate concentrations than modern recharge because commercial fertilizer commonly was not applied to agricultural fields before the 1950s. National studies have found that nitrate concentrations in ground water minimally affected by human activities were less than 2 or $3 \mathrm{mg} / \mathrm{L}$ (Madison and Brunett, 1985; Mueller and Helsel, 1996). As a simplification to provide an upper bound for nitrate concentrations adjusted for mixing, nitrate 
(A)
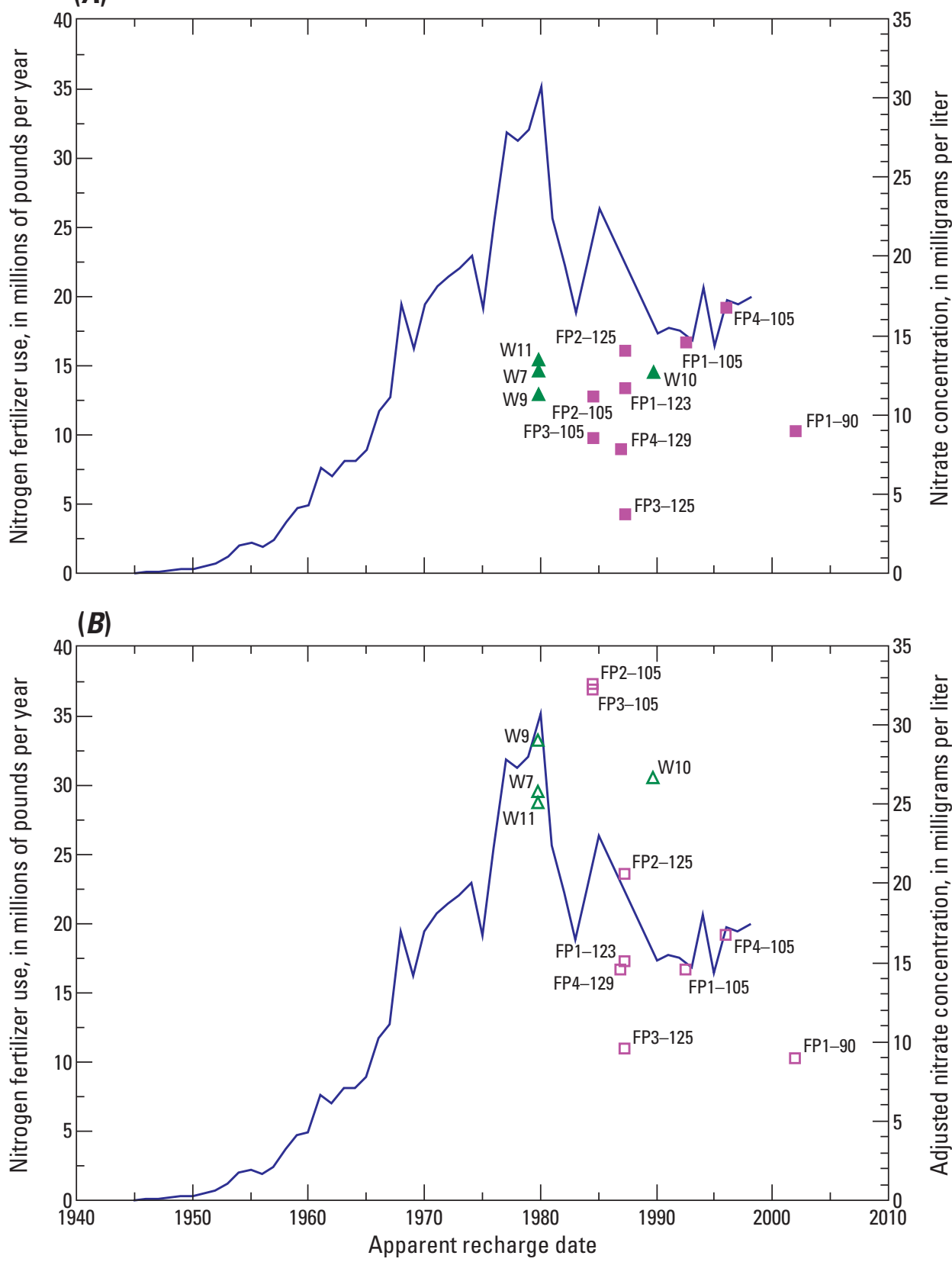

\section{EXPLANATION}

Fertilizer use

FP1-90_ Monitoring well and identifier

W10 Supply well and identifier

\section{EXPLANATION \\ - Fertilizer use \\ ․ Monitoring well- Nitrate adjusted for mixing \\ $\Delta \quad$ Supply well-Nitrate adjusted for mixing}

FP4-105 Well identifier

Figure 10. Relations between apparent recharge date and $(A)$ measured nitrate concentrations and $(B)$ nitrate concentrations of young water adjusted for mixing in ground-water samples collected near Seward, Nebraska, compared to historical nitrogen fertilizer applications in Seward County, Nebraska (Alexander and Smith, 1990; David Lorenz, U.S. Geological Survey, written commun., 1999).

concentrations in old water were assumed to be zero. The measured nitrate concentrations then were divided by the fraction of young water in the sample from age tracers (table 1 , fig. 6B) to estimate the nitrate concentration in young water. These estimated nitrate concentrations of young recharge water from the last three decades adjusted for mixing are shown in figure $10 B$.

The nitrate concentration adjusted for mixing (hereinafter called mixing-adjusted nitrate concentrations) appear to be related to the historical nitrogen fertilizer applications more strongly than the measured nitrate concentrations (fig. 10). Although there is a wide range in mixing-adjusted nitrate concentrations for mixed water samples from the mid- to late-1980s, the general pattern is one of decreases in mixingadjusted nitrate concentrations from apparent recharge dates of about 1980 to 2002 (Kendall's Tau $=-0.42, \mathrm{p}=0.0408$ ). However, there are relatively few data points, and only one sample had an apparent recharge date after 1996 making this conclusion subject to some uncertainties. The decreases in mixing-adjusted nitrate concentrations occur during a period 
of generally decreasing nitrogen fertilizer applications. Total annual nitrogen fertilizer use in Seward County was estimated from fertilizer sales to be about 19,700,000 lb in 1998, or about 53 lb/acre (Alexander and Smith, 1990; David Lorenz, U.S. Geological Survey, written commun., 1999). Historical nitrogen fertilizer use in Seward County increased from 1945 to 1980 , decreased between 1980 and 1990, and then remained somewhat steady between 1990 and 2001.

The interpretation that mixing-adjusted nitrate concentrations in young ground water have decreased in response to decreases in nitrogen fertilizer applications over the past 25 years is subject to the following uncertainties and assumptions: (1) it is assumed that countywide nitrogen fertilizer applications estimated from fertilizer sales reflect the historical pattern of fertilizer applications in the local study area; (2) ground-water samples indicating recharge dates from the 1980s and early 1990s are mixtures of young-water fractions having modern atmospheric tracers and nitrate concentrations and old-water fractions containing no modern tracers or nitrate; (3) mixing fractions (or percentages of young water) are accurately calculated using the $\mathrm{CFC}-12$ and ${ }^{3} \mathrm{H} /{ }^{3} \mathrm{He}$ tracers (table 1); (4) estimates of the apparent recharge dates are unbiased; (5) all of the nitrate in the mixed samples is from the young-water fraction; if nitrate concentrations in "old" water are non-zero, the mixing-adjusted nitrate concentrations would be less and relations of age to nitrate concentrations might be weaker; and (6) historical nitrogen fertilizer applications have been uniform spatially across the study area, and the applications only change through time; substantial lateral variations in fertilizer application rates affecting different wells in the study area could invalidate the assumptions of the historical nitrate reconstructions.

Age-dating techniques can estimate the amount of time that water and solutes have resided in the saturated zone. However, the time it takes for recharging water to percolate through the unsaturated zone and reach the aquifer also needs to be considered in the historical reconstructions of nitrate. Traveltimes for water and solutes through the unsaturated zone can range from days to centuries depending upon factors such as depth to water, physical properties of the unsaturated zone, climate, and land-use practices. Recent studies of unsaturated zone traveltimes in the High Plains aquifer in western Nebraska, Kansas, and Texas indicate that water and solutes moved along both fast and slow paths (McMahon and others, 2006); traveltimes along fast paths can range from days to years; traveltimes along slow paths can range from decades to centuries. The study sites of McMahon and others (2006) were sites with less precipitation and greater evapotranspiration than the Seward, Nebraska, study area sites. Therefore, it is expected that traveltimes through the unsaturated zone in the Seward study area would be less than those determined by McMahon and others (2006). Nevertheless, multiyear delays between fertilizer application and arrival of resulting nitrate at the water table can create unknown offsets between applications and ground-water nitrate concentrations.

\section{Summary}

The U.S. Geological Survey, in cooperation with the City of Seward, Nebraska, conducted a 2-year study from 2003 to 2004 of ground-water ages and quality to improve understanding of: (1) traveltimes from recharge areas to supply wells, (2) the effects of geochemical reactions in the aquifer on water quality, and (3) how water quality has changed historically in response to land-use practices. Three monitoring wells screened at different depths in the aquifer were installed in each of four monitoring-well nests within $2 \mathrm{mi}$ of the Seward west well field along estimated ground-water flow paths towards the well field from the northwest and southwest. Historical ground-water altitude data indicate that ground-water flow may converge on the area of the well field from these directions.

The High Plains aquifer in the study area has a depth to water table ranging from 75 to $96 \mathrm{ft}$ below land surface. The aquifer consists of coarse sand and gravel with a saturated thickness of about $50 \mathrm{ft}$ or less. Supply wells typically are screened in the bottom $20 \mathrm{ft}$ of the aquifer. The aquifer is underlain by glacial till and overlain by loess and clay soils.

Ground-water levels were measured in monitoring wells beginning in July 2004 to allow comparison of spatial and temporal variations in ground-water levels and flow patterns to ground-water age and chemistry data. Ground-water-level data collected for this study indicated seasonal changes in water levels, with summer irrigation season water levels 4 to $12 \mathrm{ft}$ below winter levels. Vertical hydraulic-head gradients in well nests generally were very small, consistent with mostly horizontal ground-water flow within the aquifer towards the Seward west well field.

Concentrations of three different chlorofluorocarbons (CFC-12, CFC-11, and CFC-113), sulfur hexafluoride $\left(\mathrm{SF}_{6}\right)$, and ratios of tritium $\left({ }^{3} \mathrm{H}\right)$ to helium-3 $\left({ }^{3} \mathrm{He}\right)$ isotope derived from radioactive decay of ${ }^{3} \mathrm{H}$ were used to estimate the apparent recharge age of ground-water samples. Age estimates were based primarily on $\mathrm{CFC}-12$ and ${ }^{3} \mathrm{H} /{ }^{3} \mathrm{He}$ data. Estimates of apparent ground-water age from tracer data were complicated by mixing of water having different ages in 10 of the 13 ground-water samples collected, differences between results for different tracers because of lag effects caused by relatively large depths to water, and apparent geologic sources of ${ }^{3} \mathrm{He}$ and $\mathrm{SF}_{6}$.

Estimated apparent recharge dates of unmixed groundwater samples or mean ages of young fractions of mixed water in samples collected from monitoring wells ranged from 1985 to 2002. For monitoring-well samples containing mixed water, the fraction of the sample consisting of young water ranged from 26 to 77 percent of the sample. Estimated mean apparent recharge dates of young fractions of mixed water in samples collected from four supply wells in the Seward west well field ranged from about 1980 to 1990. Estimated fractions of the supply-well samples consisting of young water ranged from 39 to 54 percent. It is implicit in the mixing calculations that 
the remainder of the sample that is not young water consists of water that is more than 60 years old and contains no detectable quantities of modern atmospheric tracers. Estimated fractions of the mixed samples composed of "old" water ranged from 23 to 74 percent. Although alternative mixing models can be used to interpret the results, the mean ages and mixing fractions for the primary mixing models used were fairly similar.

All of the samples collected contained at least some water that recharged the aquifer in the last 25 years. Relations of ground-water apparent ages or mean ages of water mixtures with depth were not consistent. In two of the well nests, changes in mean apparent age from the shallowest to the deepest sample were 15 and 9 years. However, mean ages in the deepest wells in two other well nests were slightly younger, and fractions of young water in the sample were less in the shallow samples. The occurrence of more young water in the deep rather than intermediate parts of the aquifer at these locations is consistent with the effects of pumping from irrigation and supply wells, which are screened primarily in the bottom of or throughout the entire aquifer. Withdrawals from the lower part of the aquifer have the effect of drawing younger water from shallower depths to the deeper part of the aquifer, perhaps leaving less young ground water at intermediate depths away from the depths of supply-well screens. Such mixing is not surprising considering that in the study area the High Plains aquifer is relatively thin $(50 \mathrm{ft})$ and has a relatively high density of wells (4.75 irrigation wells per square mile plus supply wells), indicating that withdrawals are relatively large. Such pumping stress has the effect of increasing groundwater velocities and mixing of ground water.

Horizontally, water age along estimated ground-water flow paths did not follow a clear pattern of younger to older with distance along the flow path towards the supply wells. The complex pattern of ages probably is affected at least partially by pumping in the aquifer and precludes calculating meaningful horizontal traveltimes in most cases. The most reliable estimate of horizontal traveltimes, made on the basis of differences in ages between the shallow monitoring well at the upgradient end of the northwest well transect and the deep well at the downgradient end of the well transect, was 9 years to travel this distance of about $2 \mathrm{mi}$. Although hydraulic heads indicate such a ground-water flow path is conceptually reasonable, the presence of water of older ages in between these wells and the likely complexity of ground-water flow due to a highly pumped system suggest that it is not certain that these two wells are along a true ground-water flow path. The general similarity of water ages at similar depths between different well nests is consistent with the fact that horizontal flow in the aquifer is relatively rapid. These results may indicate that traveltimes in the studied area are much less than the 30-year traveltime estimated from simple analytical modeling to delineate wellhead protection areas.

Results from sampling four supply wells indicated that water quality was generally suitable for drinking with regard to major ions, trace elements, and pesticide compounds. However, nitrate concentrations in untreated water from all four of the supply wells were larger than the USEPA MCL of $10 \mathrm{mg} / \mathrm{L}$, ranging from 11.3 to $13.5 \mathrm{mg} / \mathrm{L}$. Nitrate and dissolved-solids concentrations in water from monitoring wells in the aquifer were not consistently related to depth in this study, probably because of mixing related to ground-water pumping. It also is unlikely that nitrate concentrations in the aquifer near the Seward west well field are decreased by denitrification in the aquifer because the oxic geochemical conditions do not favor the occurrence of this reaction; there was no evidence of excess nitrogen gas that might indicate the reaction is occurring.

Nitrate concentrations coupled with water recharge dates were compared to historical estimated fertilizer application in an attempt to reconstruct historical trends in ground-water nitrate concentrations and their relation to land-use practices. Historical nitrogen fertilizer use in Seward County increased from 1945 to 1980, decreased between 1980 and 1990, and then remained somewhat steady between 1990 and 2001. Relations of measured nitrate concentrations corresponding to estimated recharge ages and historical fertilizer applications were not evident. However, nitrate concentration in youngwater fractions after adjustment for mixing appeared to be related to the historical nitrogen fertilizer applications more strongly than the measured nitrate concentrations. Although there is a wide range in mixing-adjusted nitrate concentrations for mixed-water samples from the mid- to late-1980s, the general pattern is one of decreases in mixing-adjusted nitrate concentrations from apparent recharge dates of about 1980 to 2002, which corresponds to a period of generally decreasing nitrogen fertilizer applications. The interpretation that nitrate concentrations in ground water have decreased in response to decreases in nitrogen fertilizer applications over the past 25 years is subject to several uncertainties and assumptions.

\section{References Cited}

Alexander, R.B., and Smith, R.A., 1990, County-level estimates of nitrogen and phosphorus fertilizer use in the United States, 1945 to 1985: U.S. Geological Survey OpenFile Report 90-130, available on Web, accessed July 14, 2005, at http://pubs.usgs.gov/of/1990/ofr90130/report.htm

Alley, W.M., and Emery, P.A., 1986, Groundwater model of the Blue River Basin, Nebraska - twenty years later: Journal of Hydrology, v. 85, p. 225-249.

American Public Health Association, 1998, Standard methods for the examination of water and wastewater (20th ed.): Washington, D.C., American Public Health Association, American Water Works Association, and Water Environment Federation, p. 3-37 to 3-43.

Böhlke, J.K., 2002, Groundwater recharge and agricultural contamination: Hydrogeology Journal, v. 10, p. 153-179. 
Böhlke, J.K., in press, TRACERMODEL1-Excel workbook for calculation and presentation of environmental tracer data for simple groundwater mixtures, in IAEA Guidebook on the use of chlorofluorocarbons in hydrology: Vienna, International Atomic Energy Agency.

Busenberg, Eurybiades, and Plummer, L.N., 1992, Use of chlorofluorocarbons $\left(\mathrm{CCl}_{3} \mathrm{~F}\right.$ and $\left.\mathrm{CCl}_{2} \mathrm{~F}_{2}\right)$ as hydrologic tracers and age-dating tools - the alluvium and terrace system of central Oklahoma: Water Resources Research, v. 28, no. 9 , p. 2257-2283.

Busenberg, Eurybiades, and Plummer, L.N., 2000, Dating young ground water with sulfur hexafluoride-natural and anthropogenic sources of sulfur hexafluoride: Water Resources Research, v. 36, no. 10, p. 3011-3030.

Cady, R.E., and Ginsburg, M.H., 1979, Interpretative study and numerical model of the hydrogeology of Upper Big Blue Natural Resources District: Lincoln, Conservation and Survey Division, University of Nebraska-Lincoln, 185 p.

Childress, C.J. Oblinger, Foreman, W.T., Connor, B.F., and Maloney, T.J., 1999, New reporting procedures based on long-term method detection levels and some considerations for interpretations of water-quality data provided by the U.S. Geological Survey National Water Quality Laboratory: U.S. Geological Survey Open-File Report 99-193, 19 p.

Clark, W.B., Jenkins, W.J., and Top, Z., 1976, Determination of tritium by mass spectrometric measurement of ${ }^{3} \mathrm{He}$ : International Journal of Applied Radiation and Isotopes, v. 27 , p. 515-522.

Conservation and Survey Division of the University of Nebraska, 1980, Configuration of the water table, 1979: Lincoln, Conservation and Survey Division of the University of Nebraska, information available on the Web, accessed October 4, 2006, at http://csd.unl.edu/general/ gis-datasets.asp\#Configuration_of_the_Water_Table,_1979

Conservation and Survey Division of the University of Nebraska, 2000, Configuration of the water table, 1995: Lincoln, Conservation and Survey Division of the University of Nebraska, information available on the Web, accessed October 4, 2006, at http://csd.unl.edu/general/ gis-datasets.asp\#Configuration_of_the_Water_Table,_1995

Cook, P.G., and Böhlke, J.K., 2000, Determining timescales for groundwater flow and solute transport, in Cook, P.G., and Herczeg, A., eds., Environmental tracers in subsurface hydrology: Boston, Kluwer Academic Publishers, p. 1-30.

Cook, P.G., and Solomon, D.K., 1995, The transport of atmospheric trace gases to the water table-implications for groundwater dating with chlorofluorocarbons and krypton 85: Water Resources Research, v. 31, no. 2, p. 263-270.
Emery, P.A., 1966, Use of analog model to predict streamflow depletion, Big and Little Blue River Basin, Nebraska: Ground Water, v. 4, no. 4, p. 13-20.

Faires, L.M., 1993 Methods of analysis by the U.S. Geological Survey National Water Quality Laboratory-determination of metals in water by inductively coupled plasmamass spectrometry: U.S. Geological Survey Open-File Report 92-634, 28 p.

Fishman, M.J., 1993, Methods of analysis by the U.S. Geological Survey National Water Quality Laboratory-determination of inorganic and organic constituents in water and fluvial sediments: U.S. Geological Survey Open-File Report 93-125, 217 p.

Fishman, M.J., and Friedman, L.C., 1989, Methods for determination of inorganic substances in water and fluvial sediments: U.S. Geological Survey Techniques of WaterResources Investigations, book 5, chap. A1, 545 p.

Garbarino, J.R., 1999, Methods of analysis by the U.S. Geological Survey National Water Quality Laboratory-determination of dissolved arsenic, boron, lithium, selenium, strontium, thallium, and vanadium using inductively coupled plasma-mass spectrometry: U.S. Geological Survey Open-File Report 99-093, 31 p.

Garber, M.S., and Koopman, F.C., 1968, Methods of measuring water levels in deep wells: U.S. Geological Survey Techniques of Water-Resources Investigations, book 8, chap. A1, 23 p.

Gottula, J.J., 1990, A study of nonpoint source ground water contamination in the eastern portion of the Upper Big Blue Natural Resources District — a special area report: Lincoln, Nebraska Department of Environmental Control, Water Quality Division, Ground Water Section, variously paginated.

Gutentag, E.D., Heimes, F.J., Krothe, N.C., Luckey, R.R., and Weeks, J.B., 1984, Geohydrology of the High Plains aquifer in parts of Colorado, Kansas, Nebraska, New Mexico, Oklahoma, South Dakota, Texas, and Wyoming: U.S. Geological Survey Professional Paper 1400-B, 63 p.

High Plains Climate Center, 2005, National Weather Service surface observations and automated weather data network data: Information available on Web, accessed July 1, 2005, at http://www.hprcc.unl.edu/data.htm

Hitch, D.E., Walczyk, V.C., Miller, J.D., Drudik, R.A., and Hull, S.H, 2005, Water resources data-Nebraskawater year 2004: U.S. Geological Survey Water-Data Report NE-04-1, 673 p. 
Huntoon, P.W., 1974, Predicted water-level declines for alternative groundwater developments in the upper Big Blue River basin, Nebraska: Lincoln, Conservation and Survey Division, University of Nebraska, Nebraska Geological Survey Resource Report No. 6, 106 p.

Johnson, C.R., and Keech, C.F., 1959, Geology and ground water resources of the Big Blue River Basin above Crete, Nebraska: U.S. Geological Survey Water-Supply Paper 1474, 94 p.

Keech, C.F, 1978, Water resources of Seward County, Nebraska: Lincoln, Conservation and Survey Division of the University of Nebraska, Water Survey Paper 46, 88 p.

Lindley, C.E., Stewart J.T., and Sandstrom, M.W., 1996, Determination of low concentrations of acetochlor in water by automated solid-phase extraction and gas chromatography with mass selective detection: Journal of AOAC International, v. 79, no. 4, p. 962-966.

Luckey, R.R., Gutentag, E.D., Heimes, F.J., and Weeks, J.B., 1986, Digital simulation of ground-water flow in the High Plains aquifer in parts of Colorado, Kansas, Nebraska, New Mexico, Oklahoma, South Dakota, Texas, and Wyoming: U.S. Geological Survey Professional Paper 1400-D, 63 p.

Madison, R.J., and Brunett, J.O., 1985, Overview of the occurrence of nitrate in ground water of the United States, in National Water Summary 1984-hydrologic events, selected water-quality trends, and groundwater resources: U.S. Geological Survey Water-Supply Paper 2275, p. 93-105.

Madsen, J.E., Sandstrom, M.W., and Zaugg, S.D., 2003, Methods of analysis by the U.S. Geological Survey National Water Quality Laboratory - a method supplement for the determination of fipronil and degradates in water by gas chromatography/mass spectrometry: U.S. Geological Survey Open-File Report 02-462 11 p.

McMahon, P.B., Dennehy, K.F., Bruce, B.W., Böhlke, J.K., Michel, R.L., Gurdak, J.J., and Hurlbut, D.B., 2006, Storage and transit time of chemicals in thick unsaturated zones under rangeland and irrigated cropland, High Plains, United States: Water Resources Research, v. 42, W03413, doi:10.1029/2005WR004417.

Mueller, D.K., and Helsel, D.R., 1996, Nutrients in the Nation's water-too much of a good thing?: U.S. Geological Survey Circular 1136, 24 p.

National Agricultural Statistics Service, 2002, County summary highlights, 2002: U.S. Department of Agriculture, information available on Web, accessed February 8, 2006, at http://www.nass.usda.gov/Data_and_Statistics/Quick_Stats/
Nebraska Department of Natural Resources, 2002, Monthly precipitation in inches-station 25-7715: Information available on Web, accessed February 9, 2006, at http://dnrdata. dnr.state.ne.us/Rainfall/

Nebraska Department of Natural Resources, 2006, Registered groundwater wells database: Nebraska Department of Natural Resources, information available on Web, accessed February 9, 2006, at http://dnrdata.dnr.ne.gov/wellssql/

Nebraska Natural Resources Commission, 1983, Report on the Big and Little Blue River Basins area planning study, Technical Appendix A-groundwater resources, development, calibration, verification and utilization of the groundwater models: Lincoln, Nebraska Natural Resources Commission, variously paginated.

Östlund, H.G., 1987, Tritium: GEOSECS Atlantic, Pacific, and Indian Ocean Expeditions, v. 7, p. 7-10.

Patton, C.J., and Kryskalla, J.R., 2003, Methods of analysis by the U.S. Geological Survey National Water Quality Laboratory-evaluation of alkaline persulfate digestion as an alternative to Kjeldahl digestion for determination of total and dissolved nitrogen and phosphorus in water: U.S. Geological Survey Water-Resources Investigations Report 03-4174, $33 \mathrm{p}$.

Sandstrom, M.W., Stropple, M.E., Foreman, W.T., and Schroeder, M.P., 2001, Methods of analysis by the U.S. Geological Survey National Water Quality Laboratory-determination of moderate-use pesticides and selected degrates in water by C-18 solid-phase extraction and gas chromatography/mass spectrometry: U.S. Geological Survey WaterResources Investigations Report 01-4098, 70 p.

Schlosser, Peter, Stute, Martin, Dörr, H., Sonntag, Christian, and Münnich, K.O., 1988, Tritium $/{ }^{\beta} \mathrm{He}$ dating of shallow groundwater: Earth and Planetary Science Letters, v. 89, p. 353-362.

Schlosser, Peter, Stute, Martin, Sonntag, Christian, and Münnich, K.O., 1989, Tritiogenic ${ }^{3} \mathrm{He}$ in shallow groundwater: Earth and Planetary Science Letters, v. 94, p. 245-256.

Solomon, D.K., Cook, P.G., and Stanford, W.E., 1998, Dissolved gases in subsurface hydrology, chapter 9, in Kendall, C., and McDonnell, J.J., eds., Isotope tracers in catchment hydrology: Amsterdam, Elsevier Science B.V., p. 291-318.

Solomon, D.K., Poreda, R.J., Schiff, S.L., and Cherry, J.A., 1992, Tritium and helium-3 as groundwater age tracers in the Borden aquifer: Water Resources Research, v. 28, no. 3, p. 741-755.

Trevors, J.T., 1985, The influence of oxygen concentrations on denitrification in soil: Applied Microbiology and Biotechnology, v. 23, no. 2, p. 152-155. 
U.S. Environmental Protection Agency, 2004, 2004 Edition of the drinking water standards and health advisories: Washington, D.C., Office of Water, EPA 822-R-04-005, 12 p.

U.S. Geological Survey, variously dated, National field manual for the collection of water-quality data: U.S. Geological Survey Techniques of Water-Resources Investigations, book 9, chaps. A1-A9, available on the Web, accessed January 17, 2003, at http://pubs.water.usgs.gov/twri9A

U.S. Geological Survey, 2005, Sampling instructions: U.S. Geological Survey information available on the Web, accessed February 10, 2006, at http://water.usgs.gov/lab

U.S. Geological Survey, 2007, National Water Information System Web interface, USGS ground-water data for Nebraska: U.S. Geological Survey data, accessed March 12, 2007, at http://waterdata.usgs.gov/ne/nwis/gw/

U.S. Geological Survey Chlorofluorocarbon Laboratory, 2006a, Analytical procedures for dissolved gases: U.S. Geological Survey information available on Web, accessed May 14, 2007, at http://water.usgs.gov/lab/dissolved-gas/ lab/analytical_procedures/

U.S. Geological Survey Chlorofluorocarbon Laboratory, 2006b, Analytical procedures for CFCs: U.S. Geological Survey information available on Web, accessed May 14, 2007, at http://water.usgs.gov/lab/chlorofluorocarbons/lab/ analytical_procedures/

U.S. Geological Survey Chlorofluorocarbon Laboratory, 2006c, Analytical procedures for $\mathrm{SF}_{6}$ : U.S. Geological Survey information available on Web, accessed May 14, 2007, at http://water.usgs.gov/lab/sf6/lab/analytical_procedures/
Verstraeten, I.M., McGuire, V.L., and Heckman, K.L., 1998, Hydrogeology and subsurface nitrate in the Upper Big Blue Natural Resources District, central Nebraska, July 1995 through September 1997: U.S. Geological Survey WaterResources Investigations Report 98-4207, 81 p.

Zaugg, S.D., Sandstrom, M.W., Smith, S.G., and Fehlberg, K.M., 1995, Methods of analysis by the U.S. Geological Survey National Water Quality Laboratory-determination of pesticides in water by $\mathrm{C}-18$ solid-phase extraction and capillary-column gas chromatography/mass spectrometry with selected ion-monitoring: U.S. Geological Survey Open-File Report 95-181, 60 p. 


\section{Appendixes}




\section{Appendix 1. Well Installation}

Well-construction information for monitoring wells installed for this study by the City of Seward is given in table 4. 


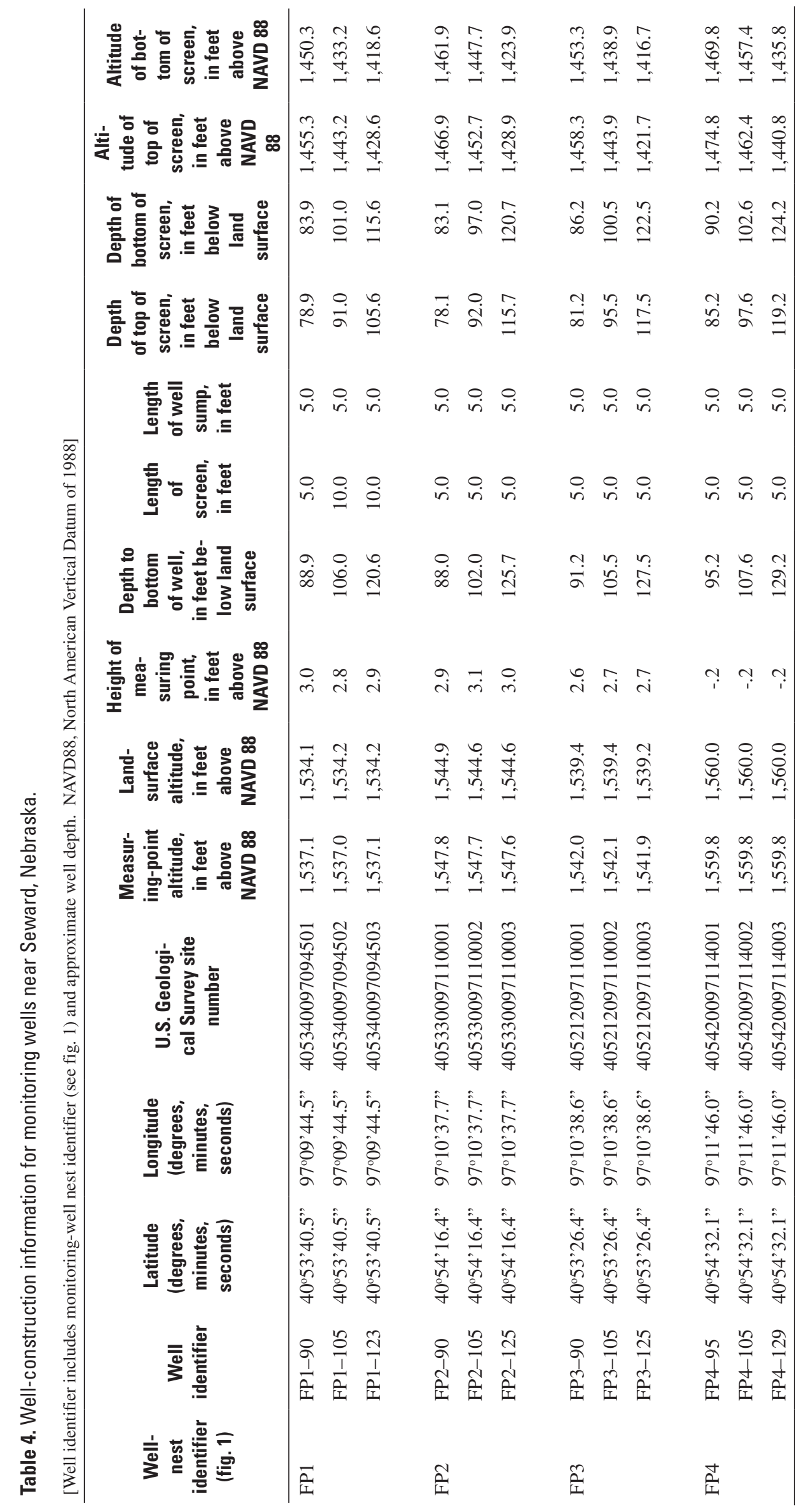




\section{Appendix 2. Estimation of Ground- Water Age}

Three different methods were used to estimate groundwater age in the study - the $\mathrm{CFC}, \mathrm{SF}_{6}$, and ${ }^{3} \mathrm{H} /{ }^{3} \mathrm{He}$ methods. The $\mathrm{CFC}$ and $\mathrm{SF}_{6}$ estimates of ground-water age are based upon the increase in concentrations of these trace gases in the atmosphere since the 1940s and 1950s because of industrial use of these compounds (Busenburg and Plummer, 1992, 2000; U.S. Geological Survey, 2005). CFCs (or freons) are stable organic compounds first produced in the 1930s as refrigerants but also were used as aerosol propellants, cleaning agents, solvents, and blowing agents in the production of foam rubber and plastics. All CFCs eventually are released to the atmosphere and then are transported through the atmosphere to the hydrosphere. Concentrations of these gases in the atmosphere have increased in a nearly linear fashion since the 1940s, although concentrations of CFCs in the atmosphere have leveled off or declined in the last 10 years following implementation of an international treaty to ban CFC production in 1992. Substantial production of $\mathrm{SF}_{6}$ began in the 1960s for use in high-voltage electrical switches, and atmospheric concentrations of $\mathrm{SF}_{6}$ have continued increasing since that time; $\mathrm{SF}_{6}$ is very stable in the atmosphere.

The concentrations of $\mathrm{CFCs}$ and $\mathrm{SF}_{6}$ in the atmosphere are proportional to concentrations in recharge water entering an aquifer at that time, with the proportionality determined by the recharge temperature, which is estimated from concentrations of dissolved nitrogen and argon gas. If there are no other sources or sinks for these compounds in the aquifer and the effects of dispersion are minimal, the concentrations of these compounds in the ground water at the time of recharge are preserved and indicate the approximate date that the water entered the aquifer. The three individual $\mathrm{CFC}$ compounds ( $\mathrm{CFC}-12$, CFC-11, and CFC-113), each having a different historical atmospheric concentration trend, provide three independent age estimates.

The ${ }^{3} \mathrm{H} /{ }^{3} \mathrm{He}$ method of ground-water age dating is based upon the increase in ${ }^{3} \mathrm{H}$ concentrations in precipitation that occurred following atmospheric hydrogen bomb testing in the 1950s and 1960s (Schlosser and others, 1988, 1989; Solomon and others, 1992; U.S. Geological Survey, 2005). Peak ${ }^{3} \mathrm{H}$ concentrations occurred in 1963 and have declined substantially since then. The presence of ${ }^{3} \mathrm{H}$ indicates that some of the water in the sample has recharged the aquifer since the early 1950s. However, concentrations of ${ }^{3} \mathrm{H}$ alone cannot provide an unambiguous apparent age because similar ${ }^{3} \mathrm{H}$ values in precipitation have occurred over multiple years. However, ${ }^{3} \mathrm{H}$ radioactively decays to ${ }^{3} \mathrm{He}$ with a half-life of 12.43 years. By determining the ratio of ${ }^{3} \mathrm{H}$ to ${ }^{3} \mathrm{He}$ derived from decay of ${ }^{3} \mathrm{H}$, the apparent time that the water has resided in the aquifer can be determined precisely. Helium also can be produced naturally by sediment; the amount of ${ }^{3} \mathrm{He}$ derived from ${ }^{3} \mathrm{H}$ decay rather than geologic sources is estimated using ${ }^{3} \mathrm{He} /{ }^{4} \mathrm{He}$ ratios and neon $(\mathrm{Ne})$ gas concentrations.
Concentrations of dissolved gases and estimated recharge temperatures are shown in table 5. Recharge temperatures calculated from dissolved nitrogen and argon concentrations generally compared well with ground-water temperatures measured at the time of sampling; measured ground-water temperatures are subject to some uncertainties depending upon the length of sampling lines and environmental conditions at the time of sampling. A few dissolved gas recharge temperatures were a few degrees higher than the average annual air temperature of $13{ }^{\circ} \mathrm{C}$ (High Plains Climate Center, 2005) or onsite-measured water temperatures of 14 to $15^{\circ} \mathrm{C}$ in monitoring wells; these variations in recharge temperature were considered real variations in recharge temperatures. Recharge temperatures and quantities of excess air calculated from dissolved-gas concentrations were used directly as input to estimate $\mathrm{CFC}$ and $\mathrm{SF}_{6}$ concentrations expected in recharge water on the basis of historical atmospheric concentrations. Resulting age estimates were not very sensitive to small adjustments in recharge temperature. In the most extreme case of uncertainty in recharge temperatures, changing the recharge temperature from 17.9 to $12.0^{\circ} \mathrm{C}$ changed the piston-flow model recharge age for $\mathrm{CFC}-11$ and $\mathrm{CFC}-12$ by 6 years. Concentrations of age-dating tracers and related data used for correcting or estimating ages are shown in table 6 .

To estimate ground-water ages from atmospheric tracer data, measured tracer and ${ }^{3} \mathrm{H}$ values were compared to those expected from different lumped-parameter models including a piston-flow model (PFM), binary-mixing model (BMM), exponential-mixing model (EMM), and binary mixing of exponentially mixed water (EBMM) (Cook and Böhlke, 2000). Excel workbooks for calculation and presentation of environmental tracer data for simple ground-water mixtures of Böhlke (in press) were used for analysis of the data. Example plots are shown in figures 2-1, 2-2, and 2-3. Measured concentrations of particular tracers also were compared to those of other tracers. This estimation process was iterative, and refinements were made on the basis of estimates of multiple tracers $\left(\mathrm{CFC}-12, \mathrm{CFC}-11, \mathrm{CFC}-113,{ }^{3} \mathrm{H} /{ }^{3} \mathrm{He}, \mathrm{SF}_{6},{ }^{3} \mathrm{H}\right)$ and samples. Historical atmospheric concentrations of tracers were obtained from the USGS Chlorofluorocarbon Laboratory. Monthly concentrations of tritium in precipitation since 1953 for the Seward, Nebraska, area were estimated using a program that calculates tritium concentrations for a user-specified latitude/longitude by extrapolating results from stations where tritium in precipitation has been measured (Robert L. Michel, Research Hydrologist, U.S. Geological Survey, written commun., August 31, 2004). Tritium concentrations then were corrected for radioactive decay to the time of sampling in 2003 and 2004.

The simplest model is a piston-flow model (PFM). The PFM presumes that water entering the aquifer moves through the aquifer system without mixing and retains the original concentration of the water at the time of recharge (Cook and Böhlke, 2000). This theoretical ideal is a simplification but can be a reasonable approximation in some simple aquifer systems. If tracer results suggest mixing, several different mixing 
Table 5. Dissolved-gas concentrations and estimated recharge temperatures and excess air quantities in ground-water samples collected from monitoring and supply wells near Seward, Nebraska, 2003-04.

[Replicate analyses are shown for most samples. NAVD 88, North American Vertical Datum of 1988; mg/L, milligrams per liter]

\begin{tabular}{|c|c|c|c|c|c|c|c|c|c|c|}
\hline $\begin{array}{l}\text { Well identi- } \\
\text { fier } \\
\text { (fig. 1) }\end{array}$ & $\begin{array}{c}\text { Date } \\
\text { collected } \\
\text { (month/day/ } \\
\text { year) }\end{array}$ & $\begin{array}{c}\text { Time } \\
\text { collected } \\
\text { (24-hour) }\end{array}$ & $\begin{array}{c}\text { Water } \\
\text { temperature } \\
\text { measure- } \\
\text { ments } \\
\text { (degrees } \\
\text { Celsius) }\end{array}$ & $\begin{array}{l}\text { Estimated } \\
\text { recharge } \\
\text { altitude } \\
\text { (feet above } \\
\text { NAVD 88) }\end{array}$ & \multicolumn{3}{|c|}{ Dissolved gas concentrations } & $\begin{array}{l}\text { Calculated recharge } \\
\text { temperature from } \\
\text { dissolved nitrogen } \\
\text { and argon gas } \\
\text { concentrations } \\
\text { (degrees Celsius) }\end{array}$ & $\begin{array}{c}\text { Calculated } \\
\text { excess } \\
\text { air } \\
\text { (mg/L) }\end{array}$ & $\begin{array}{c}\text { Calculated } \\
\text { excess } \\
\text { nitrogen } \\
\text { gas } \\
\text { (mg/L) }\end{array}$ \\
\hline \multicolumn{11}{|c|}{ Monitoring wells } \\
\hline FP1-90 & $8 / 23 / 2004$ & 1200 & 15.2 & 1,540 & 18 & .60 & 0 & 17.8 & 3.1 & 0 \\
\hline \multirow[t]{2}{*}{ FP1-105 } & $8 / 23 / 2004$ & 1600 & 15.0 & 1,540 & 22 & .71 & 0 & 12.0 & 5.1 & 0 \\
\hline & $8 / 23 / 2004$ & 1600 & 15.0 & 1,540 & 22 & .71 & 0 & 12.2 & 5.4 & 0 \\
\hline FP1-123 & $8 / 23 / 2004$ & 1800 & 14.2 & 1,540 & 22 & .70 & 0 & 13.2 & 5.8 & 0 \\
\hline \multirow[t]{2}{*}{ FP2-125 } & $8 / 24 / 2004$ & 1400 & 15.2 & 1,540 & 21 & .67 & 0 & 14.9 & 5.5 & 0 \\
\hline & $8 / 24 / 2004$ & 1400 & 15.2 & 1,540 & 21 & .68 & 0 & 14.8 & 5.6 & 0 \\
\hline \multirow[t]{2}{*}{ FP3-105 } & $8 / 24 / 2004$ & 1700 & 16.3 & 1,540 & 20 & .69 & 0 & 12.1 & 3.9 & 0 \\
\hline & $8 / 24 / 2004$ & 1700 & 16.3 & 1,540 & 20 & .68 & 0 & 12.5 & 3.9 & 0 \\
\hline \multirow[t]{2}{*}{ FP3-125 } & $8 / 25 / 2004$ & 1100 & 14.3 & 1,540 & 20 & .65 & 0 & 14.2 & 3.9 & 0 \\
\hline & $8 / 25 / 2004$ & 1100 & 14.3 & 1,540 & 20 & .65 & 0 & 14.3 & 3.9 & 0 \\
\hline \multirow[t]{2}{*}{ W7 } & $11 / 14 / 2003$ & 0900 & 12.1 & 1,595 & 23 & .73 & 0 & 11.8 & 6.5 & 0 \\
\hline & $11 / 14 / 2003$ & 0900 & 12.1 & 1,595 & 23 & .74 & 0 & 11.3 & 6.5 & 0 \\
\hline \multirow[t]{2}{*}{ W9 } & $11 / 13 / 2003$ & 1500 & 12.0 & 1,595 & 23 & .72 & 0 & 12.9 & 6.5 & 0 \\
\hline & $11 / 13 / 2003$ & 1500 & 12.0 & 1,595 & 22 & .71 & 0 & 13.1 & 6.1 & 0 \\
\hline \multirow[t]{2}{*}{ W10 } & $11 / 14 / 2003$ & 1500 & 12.0 & 1,595 & 22 & .71 & 0 & 12.4 & 5.8 & 0 \\
\hline & $11 / 14 / 2003$ & 1500 & 12.0 & 1,595 & 22 & .70 & 0 & 12.9 & 5.7 & 0 \\
\hline \multirow[t]{2}{*}{ W11 } & $11 / 14 / 2003$ & 1300 & 12.1 & 1,595 & 26 & .79 & 0 & 12.1 & 10 & 0 \\
\hline & $11 / 14 / 2003$ & 1300 & 12.1 & 1,595 & 24 & .75 & 0 & 11.9 & 7.8 & 0 \\
\hline
\end{tabular}


Table 6. Tracer data used in estimating ground-water age near Seward, Nebraska, 2003-04.

[Results for replicate analyses for some analytes and samples are shown. CFC, chlorofluorocarbon; pptv, parts per trillion by volume; TU, tritium units; $\mathrm{SF}_{6}$, sulfur hexafluoride; He, helium; $\delta^{3} \mathrm{He}$, helium-3/helium-4 isotopic ratio relative to standard reference; ${ }^{3} \mathrm{He} /{ }^{4} \mathrm{He}$, helium-3/helium-4 absolute ratio; ${ }^{4} \mathrm{He}$, helium- 4 concentration; $\mathrm{Ne}$, neon concentration; $\mathrm{cm}^{3} \mathrm{STP} / \mathrm{g}$, cubic centimeters per gram at standard temperature and pressure; NA, not analyzed]

\begin{tabular}{|c|c|c|c|c|c|c|c|c|c|c|c|c|c|}
\hline \multirow{2}{*}{$\begin{array}{l}\text { Local } \\
\text { well } \\
\text { name } \\
\text { (fig. 1) }\end{array}$} & \multirow{2}{*}{$\begin{array}{c}\text { Sample } \\
\text { date } \\
\text { (month/ } \\
\text { day/year) }\end{array}$} & \multicolumn{4}{|c|}{$\begin{array}{c}\text { Calculated atmospheric mixing } \\
\text { ratio corrected for excess air and } \\
\text { recharge temperature }{ }^{1}\end{array}$} & \multirow{2}{*}{$\begin{array}{c}\text { Tri- } \\
\text { tium², } \\
\text { He in- } \\
\text { growth } \\
\text { (TU) }\end{array}$} & \multirow{2}{*}{$\begin{array}{c}\text { Tritium², } \\
\text { bottle } \\
\text { (TU) }\end{array}$} & \multirow{2}{*}{$\begin{array}{l}\text { Tritium', } \\
\text { bottle } \\
\text { (TU) }\end{array}$} & \multirow{2}{*}{$\begin{array}{c}\delta^{3} \mathrm{He}^{2} \\
\text { (per mil) }\end{array}$} & \multirow{2}{*}{$\begin{array}{c}{ }^{3} \mathrm{He}^{4} \mathrm{He}^{2} \\
\text { sample } \\
\left(\times 10^{-6}\right)\end{array}$} & \multirow{2}{*}{$\begin{array}{c}{ }^{4} \mathrm{He}^{2} \\
\left(\mathrm{~cm}^{3} \mathrm{STP} / \mathrm{g}\right. \\
\left.\mathrm{x} 10^{-8}\right)\end{array}$} & \multirow{2}{*}{$\begin{array}{c}\mathrm{Ne}^{2} \\
\left(\mathrm{~cm}^{3} \mathrm{STP} / \mathrm{g}\right. \\
\left.\times 10^{-8}\right)\end{array}$} & \multirow{2}{*}{$\begin{array}{c}\text { Per- } \\
\text { centage } \\
\text { helium- } \\
3 \text { from } \\
\text { terri- } \\
\text { genic } \\
\text { sources }\end{array}$} \\
\hline & & $\begin{array}{c}\text { CFC-11 } \\
\text { (pptv) }\end{array}$ & $\begin{array}{c}\text { CFC-12 } \\
\text { (pptv) }\end{array}$ & $\begin{array}{c}\text { CFC-113 } \\
\text { (pptv) }\end{array}$ & $\begin{array}{c}\mathrm{SF}_{6} \\
\text { (pptv) }\end{array}$ & & & & & & & & \\
\hline \multicolumn{14}{|c|}{ Monitoring wells } \\
\hline \multirow[t]{2}{*}{ FP1-90 } & $8 / 23 / 2004$ & 211 & 387 & 51 & 0.41 & 8.22 & NA & NA & 2.29 & 1.416 & 5.43 & 23.16 & -6 \\
\hline & $8 / 23 / 2004$ & 209 & 378 & 50 & .33 & NA & NA & NA & NA & NA & NA & NA & NA \\
\hline \multirow[t]{2}{*}{ FP1-105 } & $8 / 23 / 2004$ & 74 & 184 & 14 & .75 & 6.75 & 8.20 & NA & 6.72 & 1.477 & 7.96 & 28.87 & 7 \\
\hline & $8 / 23 / 2004$ & 73 & 180 & 14 & .81 & NA & NA & NA & NA & NA & NA & NA & NA \\
\hline \multirow[t]{2}{*}{ FP1-123 } & $8 / 23 / 2004$ & 40 & 113 & 4.9 & .59 & 4.92 & NA & NA & 3.36 & 1.431 & 8.92 & 28.18 & 20 \\
\hline & $8 / 23 / 2004$ & 40 & 121 & 5.0 & .65 & NA & NA & NA & NA & NA & NA & NA & NA \\
\hline \multirow[t]{2}{*}{ FP2-105 } & $8 / 24 / 2004$ & 42 & 129 & 7.3 & .48 & 2.54 & 3.15 & NA & 3.49 & 1.432 & 25.95 & 80.87 & 14 \\
\hline & $8 / 24 / 2004$ & 43 & 131 & 8.2 & .43 & NA & NA & NA & NA & NA & NA & NA & NA \\
\hline \multirow[t]{2}{*}{ FP2-125 } & $8 / 24 / 2004$ & 44 & 142 & 7.7 & .98 & 4.38 & 4.51 & NA & 1.98 & 1.411 & 8.48 & 25.49 & 24 \\
\hline & $8 / 24 / 2004$ & 48 & 141 & 8.8 & .81 & NA & NA & NA & NA & NA & NA & NA & NA \\
\hline \multirow[t]{2}{*}{ FP3-105 } & $8 / 24 / 2004$ & 42 & 103 & 13 & .49 & 2.19 & NA & NA & -3.08 & 1.341 & 7.48 & 28.42 & 3 \\
\hline & $8 / 24 / 2004$ & 43 & 105 & 14 & .54 & NA & NA & NA & NA & NA & NA & NA & NA \\
\hline \multirow[t]{2}{*}{ FP3-125 } & $8 / 25 / 2004$ & 13 & 53 & 1.5 & 1.23 & NA & 1.19 & NA & -14.11 & 1.189 & 8.66 & 25.19 & 27 \\
\hline & $8 / 25 / 2004$ & 10 & 54 & 1.2 & 1.27 & NA & NA & NA & NA & NA & NA & NA & NA \\
\hline \multirow[t]{2}{*}{ FP4-105 } & $8 / 25 / 2004$ & 187 & 447 & 60 & .70 & 6.59 & NA & NA & 12.59 & 1.558 & 5.14 & 21.89 & -4 \\
\hline & $8 / 25 / 2004$ & 189 & 439 & 60 & .72 & NA & NA & NA & NA & NA & NA & NA & NA \\
\hline \multirow[t]{3}{*}{ FP4-129 } & $8 / 25 / 2004$ & 204 & 337 & 39 & 1.90 & 2.58 & 2.92 & NA & -8.29 & 1.269 & 7.74 & 21.73 & 32 \\
\hline & $8 / 25 / 2004$ & 261 & 404 & 51 & 1.20 & NA & NA & NA & NA & NA & NA & NA & NA \\
\hline & $8 / 25 / 2004$ & 230 & 460 & 60 & NA & NA & NA & NA & NA & NA & NA & NA & NA \\
\hline \multicolumn{14}{|c|}{ Supply wells } \\
\hline \multirow[t]{2}{*}{ W7 } & $11 / 14 / 2003$ & 70 & 175 & 12 & .63 & NA & NA & 6.39 & NA & NA & NA & NA & NA \\
\hline & $11 / 14 / 2003$ & 68 & 172 & 11 & .59 & NA & NA & NA & NA & NA & NA & NA & NA \\
\hline \multirow[t]{2}{*}{ W9 } & $11 / 13 / 2003$ & 55 & 144 & 7.3 & .68 & NA & NA & 4.54 & NA & NA & NA & NA & NA \\
\hline & $11 / 13 / 2003$ & 54 & 133 & 7.0 & .63 & NA & NA & NA & NA & NA & NA & NA & NA \\
\hline \multirow[t]{2}{*}{ W10 } & $11 / 14 / 2003$ & 86 & 206 & 11 & .63 & NA & NA & 5.15 & NA & NA & NA & NA & NA \\
\hline & $11 / 14 / 2003$ & 86 & 213 & 11 & .61 & NA & NA & NA & NA & NA & NA & NA & NA \\
\hline \multirow[t]{2}{*}{ W11 } & $11 / 14 / 2003$ & 76 & 196 & 15 & NA & NA & NA & 6.23 & NA & NA & NA & NA & NA \\
\hline & $11 / 14 / 2003$ & 75 & 185 & 15 & NA & NA & NA & NA & NA & NA & NA & NA & NA \\
\hline
\end{tabular}

${ }^{1}$ Analyzed by U.S. Geological Survey Chlorofluorocarbon Laboratory, Reston, Virginia.

${ }^{2}$ Analyzed by Lamont-Doherty Earth Observatory of Columbia University, Palisades, New York.

${ }^{3}$ Analyzed by University of Miami Tritium Laboratory, Miami, Florida. 

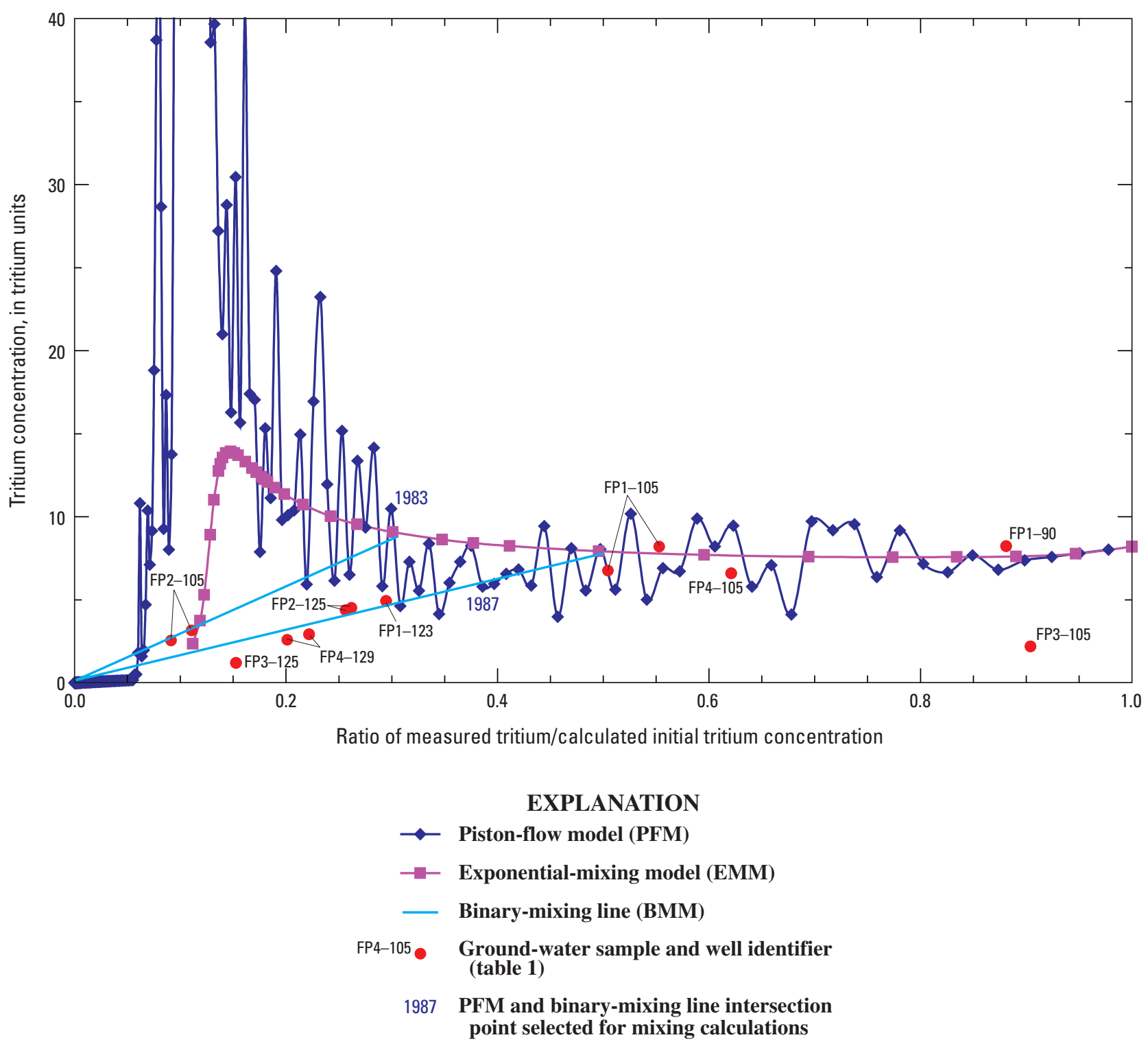

Figure 2-1. Ratio of measured tritium concentration to calculated initial tritium concentration before decay compared to tritium concentration in ground-water samples collected from monitoring wells near Seward, Nebraska, and values indicated by piston-flow and exponentialmixing models.

models can be considered. For this study binary-, exponential-, and exponential-binary mixing models were used to estimate the fraction of the sample consisting of young water having a particular mean age. In the binary-mixing model (BMM), the sample is a mixture of two subparcels, one of which is young and contains measurable tracer and one of which is too old to have measurable tracer. In the exponential-mixing model (EMM), the sample consists of a number of subparcels, each having its own tracer concentration and age, which have an exponential age distribution and an overall mean age. The mean of the combined subparcel ages affects the weight that new recharge water mixing with existing ground water has on the composition of the mixture as a whole. The EMM represents a highly mixed sample composed of water with many different ages along a distribution. The EMM has been found to be an appropriate model for ground-water ages in situations such as discharge from a spring or long-screen well in an aquifer that collects a mixture of most or all of the water in the aquifer (Cook and Böhlke, 2000). The exponential-binary mixing model (EBMM) is a binary mixture of a subparcel of water mixed according to the EMM and having a particular mean age and a subparcel that is too old to have measurable tracer.

Tritium concentrations of mixed samples were less than PFM or EMM lines (figs. 2-1, 2-2, and 2-3). However, the mixed-sample tritium concentrations can be interpreted as 


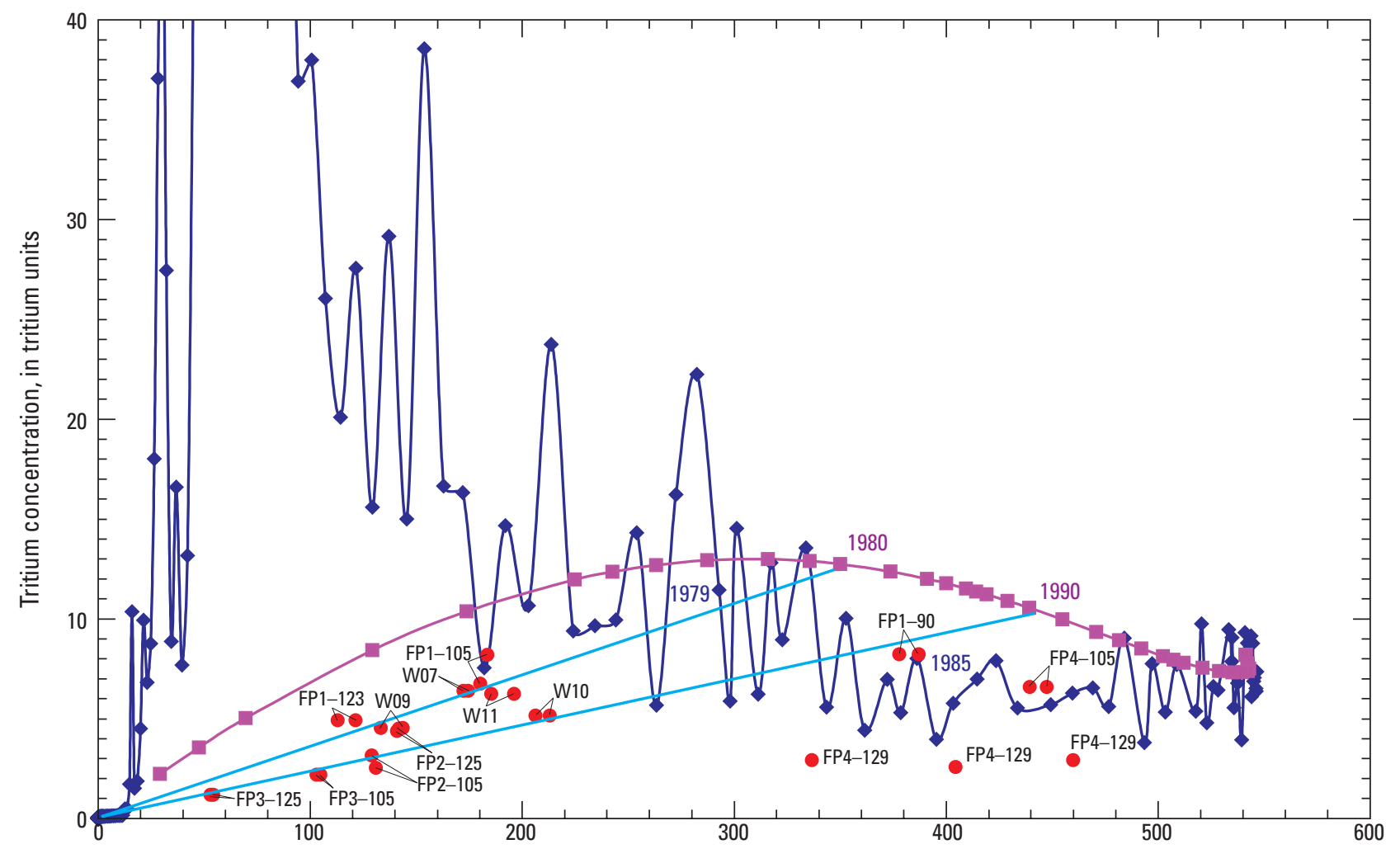

Chlorofluorocarbon-12 concentration, in parts per trillion by volume

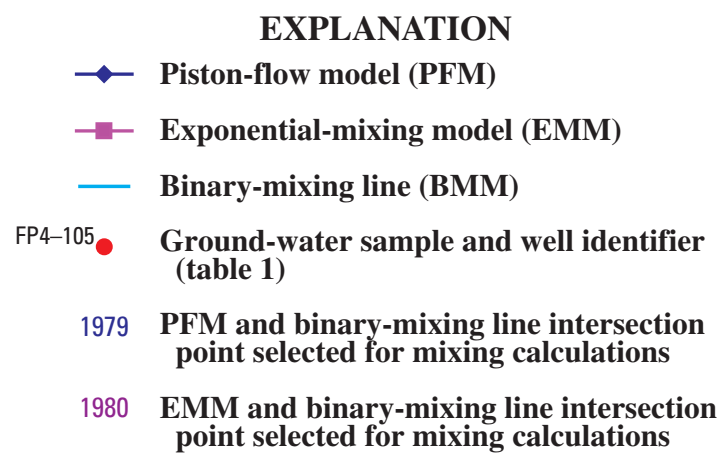

Figure 2-2. Concentration of chloroflorocarbon-12 compared to tritium concentration in ground-water samples collected from monitoring and supply wells near Seward, Nebraska, and values indicated by piston-flow and exponential-mixing models.

plotting along a linear mixing line drawn through the samples from the origin of the graph (zero concentration, old water recharge before tracers were in the atmosphere) to the point where this mixing line intersects the PFM or EMM curves. The mixing fraction is calculated from the distance that a sample plots along the mixing line between the two end members.

Monitoring-well samples showing evidence of mixing were treated as being mixtures of young piston-flow water recharged during a particular year and old water containing no tracers (BMM). The BMM was selected for monitoring wells because, away from the immediate effects of pumping wells, ground-water flow is unlikely to be a mixture of ground water of all ages in the aquifer. Rather, it was thought to be more hydrologically realistic that samples from monitoring wells may reflect mixing of young water with a narrow distribution of ages, approximated as a piston-flow age, and "old" water that may linger in parts of the aquifer with relatively slow flow or in clayey sediment.

In the case of supply wells, which pump at high rates from screens that cover nearly half the saturated thickness, mixing of water of many different ages drawn to the supply well is expected. For this situation, the exponential-mixing model (EMM) could approximate the mixing of different water that would occur in the supply well. However, tracertracer plots indicated that samples from supply wells did not 

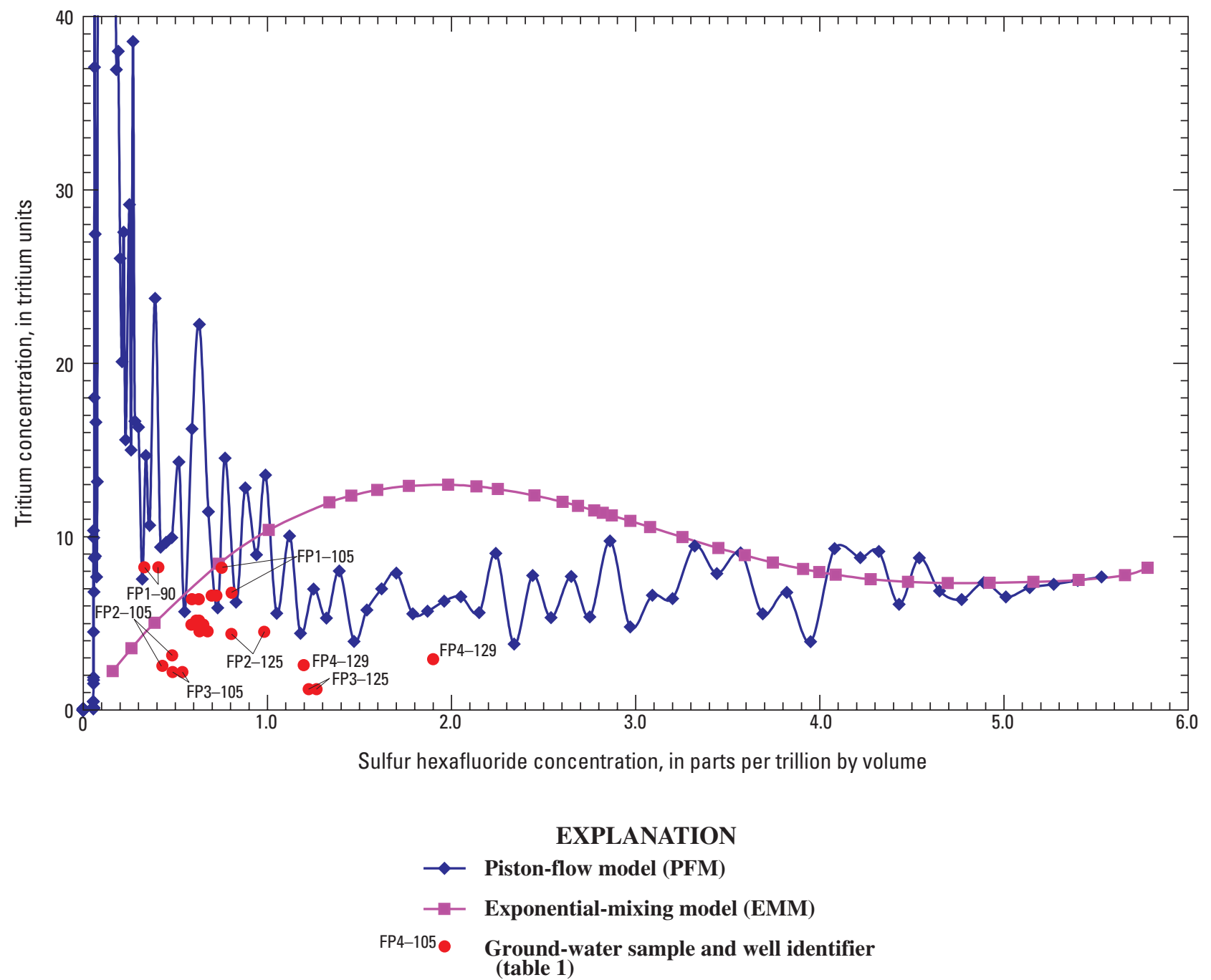

Figure 2-3. Concentration of sulfur hexafluoride compared to tritium concentration in ground-water samples collected from monitoring wells near Seward, Nebraska, and values indicated by piston-flow and exponential-mixing models.

plot along lines predicted by the EMM model (fig. 2-2). However, the supply-well samples plot along mixing lines between the EMM and zero point of the graphs; these data are consistent with tracer concentrations representing mixtures of exponentially mixed young water mixed with "old" water (EMM with binary mixing, EBMM). Such mixing is not surprising considering that the aquifer is relatively thin $(50 \mathrm{ft})$ and has a relatively high density of wells (4.75 irrigation wells per square mile plus supply wells), indicating that withdrawals are relatively large. High pumping stress has the effect of increasing ground-water velocities and mixing of ground water.

Because a higher degree of mixing for supply wells was considered more reasonable than for monitoring wells, which are pumped infrequently and at very low rates, the EBMM model was considered to be conceptually most reasonable for supply wells, whereas the BMM model was considered most reasonable for monitoring wells. In reality, the mean ages and mixing fractions for these two models were fairly similar. Results for both models are presented in table 1 .
Near Seward, the resolution of the CFC method may not be optimal because the depth to the water table of 75 to $96 \mathrm{ft}$ was large enough that $\mathrm{CFC}$ and $\mathrm{SF}_{6}$ concentrations at the water table may be in equilibrium with atmospheric concentrations from previous years rather than the current year (Solomon and others, 1998). The apparent CFC age is based on the assumption that infiltration water is in equilibrium with the atmosphere at the time of recharge. As the thickness of the unsaturated zone increases, there is increasing likelihood that the CFC concentration in soil gas at the bottom of the unsaturated zone reflects an older atmospheric concentration rather than the current atmospheric concentration. This lag time for atmospheric signals to move through the unsaturated zone may cause apparent CFC ages to be older than the true age of recharge. The ${ }^{3} \mathrm{H} /{ }^{3} \mathrm{He}$ technique is not affected by the lag time for atmospheric air to move through the unsaturated zone. The results of Cook and Solomon (1995) indicate that for similar depth to water the lag time for $\mathrm{CFC}-12$ and $\mathrm{CFC}-113$ could be 6 to 9 years and for CFC-11 could be 9 to 13 years. 
Comparison of interpreted ages from $\mathrm{CFC}-12$ and ${ }^{3} \mathrm{H} /{ }^{3} \mathrm{He}$ tracers indicated that $\mathrm{CFC}-12$ mean ages range from -1 to 20 years older than ${ }^{3} \mathrm{H} /{ }^{3} \mathrm{He}$ ages, with an average difference of 9 years (fig. 2-4). The differences between CFC-12 and ${ }^{3} \mathrm{H} /{ }^{3} \mathrm{He}$ ages were greater for relatively shallow water samples. However, the magnitude of the difference varied between sites, and there was not a difference in age using these two tracers from one sample. The average difference in age of 9 years between these tracers may reflect primarily the effect of thick unsaturated zones in causing CFC-12 ages to be older than ${ }^{3} \mathrm{H} /{ }^{3} \mathrm{He}$ ages. However, the difference in PFM-based ages of as much as 20 years in some shallow and intermediate depth samples was not expected and may not be caused entirely by the thick unsaturated-zone effect.

The differences between the two methods indicate that ages have uncertainties of approximately 10 years and as much as 20 years in some samples. Although ${ }^{3} \mathrm{H} /{ }^{3} \mathrm{He}$ ages are preferred when available because they are less susceptible to depth-to-water effects, other ${ }^{3} \mathrm{He}$ sources or processes could be affecting ${ }^{3} \mathrm{H} /{ }^{3} \mathrm{He}$ ages, and uncertainties need to be kept in mind.

Additional He sources, terrigenic He, may be present in aquifers where the rocks are enriched in uranium or thorium, or in ground-water samples in which young water has mixed with relatively old water containing terrigenic, and in some cases, mantle He (Schlosser and others, 1989). Terrigenic He was detected in seven of the nine Seward ground-water samples submitted for analysis (table 6, rightmost column, positive values indicate terrigenic He present in quantifiable amounts; negative values indicate terrigenic He less than quantifiable amounts). Terrigenic He was indicated by concentrations of ${ }^{4} \mathrm{He}$ greater than about $7 \times 10^{8} \mathrm{~cm}^{3} / \mathrm{g}$ at Standard Temperature and Pressure. Terrigenic He accounted for 2.7 to 27.4 percent of the He in the samples where it was detected. The amount of terrigenic He generally increased with depth in the aquifer. Corrections to the amount of ${ }^{3} \mathrm{He}$ derived from decay of ${ }^{3} \mathrm{H}$ rather than terrigenic ${ }^{3} \mathrm{He}$ were made by the Lamont-Doherty Laboratory; however, these corrections have uncertainties and have the effect of increasing the amount of uncertainty in the estimated age (table 6). Sample FP2-105 had a large neon concentration suggesting air contamination of the sample. ${ }^{3} \mathrm{H} /{ }^{3} \mathrm{He}$ data consequently were not used for age interpretation. Sample FP3-105 plotted off of curves of the ratio of measured tritium to calculated initial tritium concentration compared to ${ }^{3} \mathrm{H}$ concentration (fig. $2-1$ ); the sample had smaller concentrations of ${ }^{3} \mathrm{H}$ and ${ }^{3} \mathrm{He}$ derived from tritium than would be expected for samples with its measured $\mathrm{CFC}$ and $\mathrm{SF}_{6}$ concentrations. The CFC-12 ages were preferred over the ${ }^{3} \mathrm{H} /{ }^{3} \mathrm{He}$ estimates for this sample because the sample results were anomalous for ${ }^{3} \mathrm{H} /{ }^{3} \mathrm{He}$.

Naturally occurring $\mathrm{SF}_{6}$ sources may have affected some of the $\mathrm{SF}_{6}$ results, particularly in deeper ground-water samples. $\mathrm{SF}_{6}$ occurs naturally in fluid inclusions in some minerals and igneous rocks, and in some volcanic and igneous fluids (Busenberg and Plummer, 2000). Concentrations of $\mathrm{SF}_{6}$ in wells FP3-125 and FP4-129, near the bottom of the aquifer, were higher than values expected on the basis of other tracers (fig. 2-3). Similar enrichment of $\mathrm{SF}_{6}$ in deeper parts of the aquifer has been detected in samples collected from York, Nebraska, as well (unpublished data on file with the USGS, Lincoln, Nebraska). 


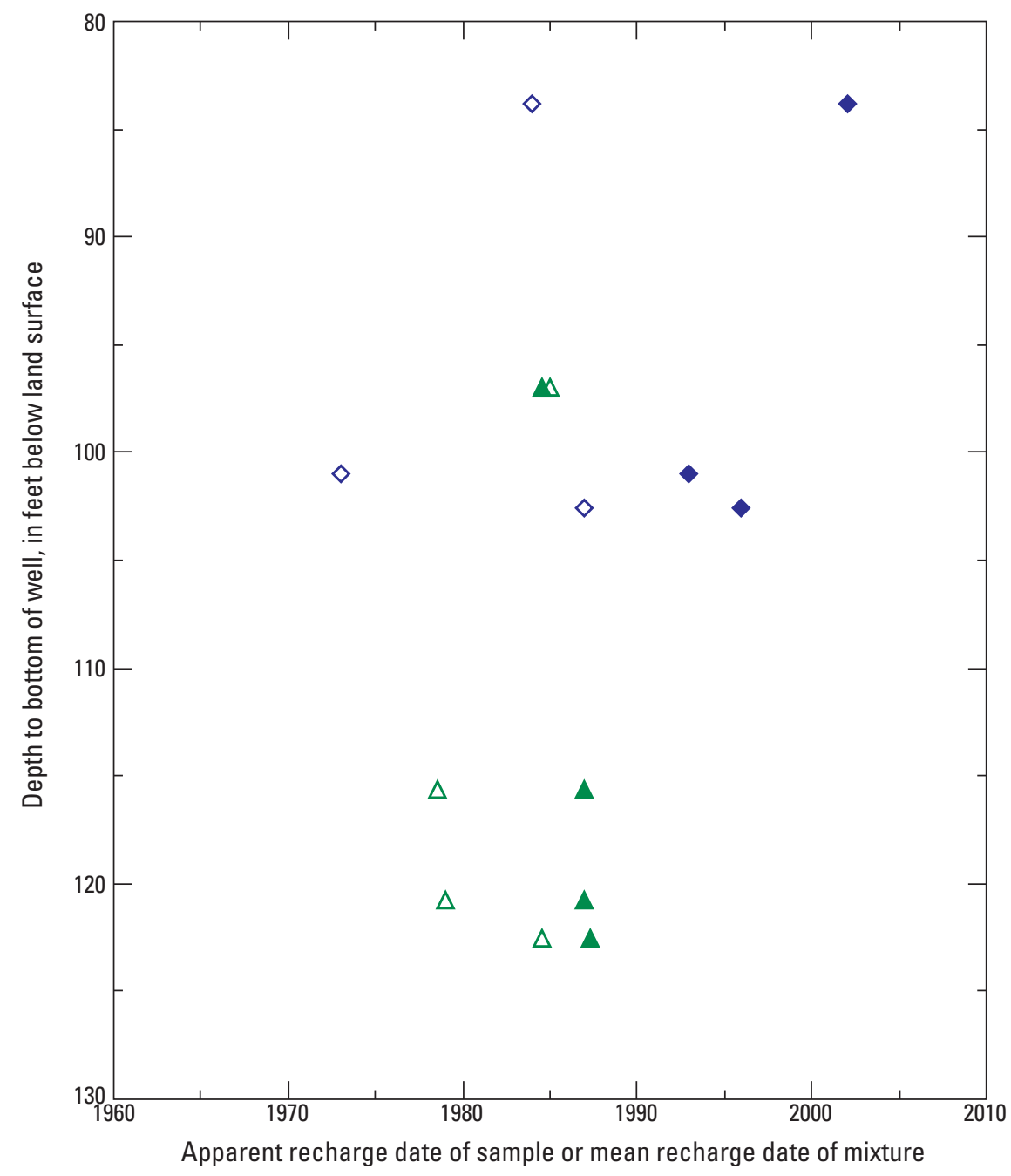

\section{EXPLANATION}

- Sample age-Piston-flow model using ratio of tritium to helium- $3\left({ }^{3} \mathrm{H} /{ }^{3} \mathrm{He}\right)$

$\diamond$ Sample age-Piston-flow model using chlorofluorocarbon-12 (CFC-12)
$\Delta$ Binary mixture-Mean age of young fraction using ratio of tritium to helium-3 $\left({ }^{3} \mathrm{H} /{ }^{3} \mathrm{He}\right)$

$\Delta$ Binary mixture-Mean age of young fraction using chlorofluorocarbon-12 (CFC-12)

Figure 2-4. Ground-water mean recharge dates determined using tritium/helium and chlorofluorocarbon-12 techniques in ground-water samples collected from monitoring wells near Seward, Nebraska. 
Prepared by Lawrence Publishing Service Center.

Edited by Lanna Combs.

Illustrations and cover design by Jeff Hartley and Mike Kemppainen.

Layout and design by Kristi Hartley.

For more information concerning the research described in this report, contact:

U.S. Geological Survey

5231 South 19th Street

Lincoln, NE 68512

(402) 328-4100

http://ne.water.usgs.gov 


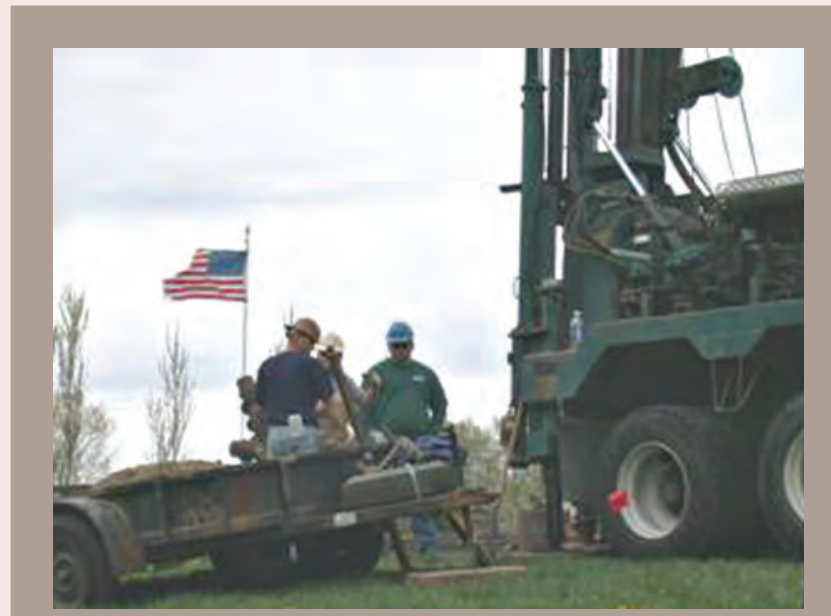

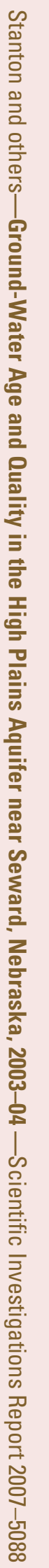

Printed on recycled paper
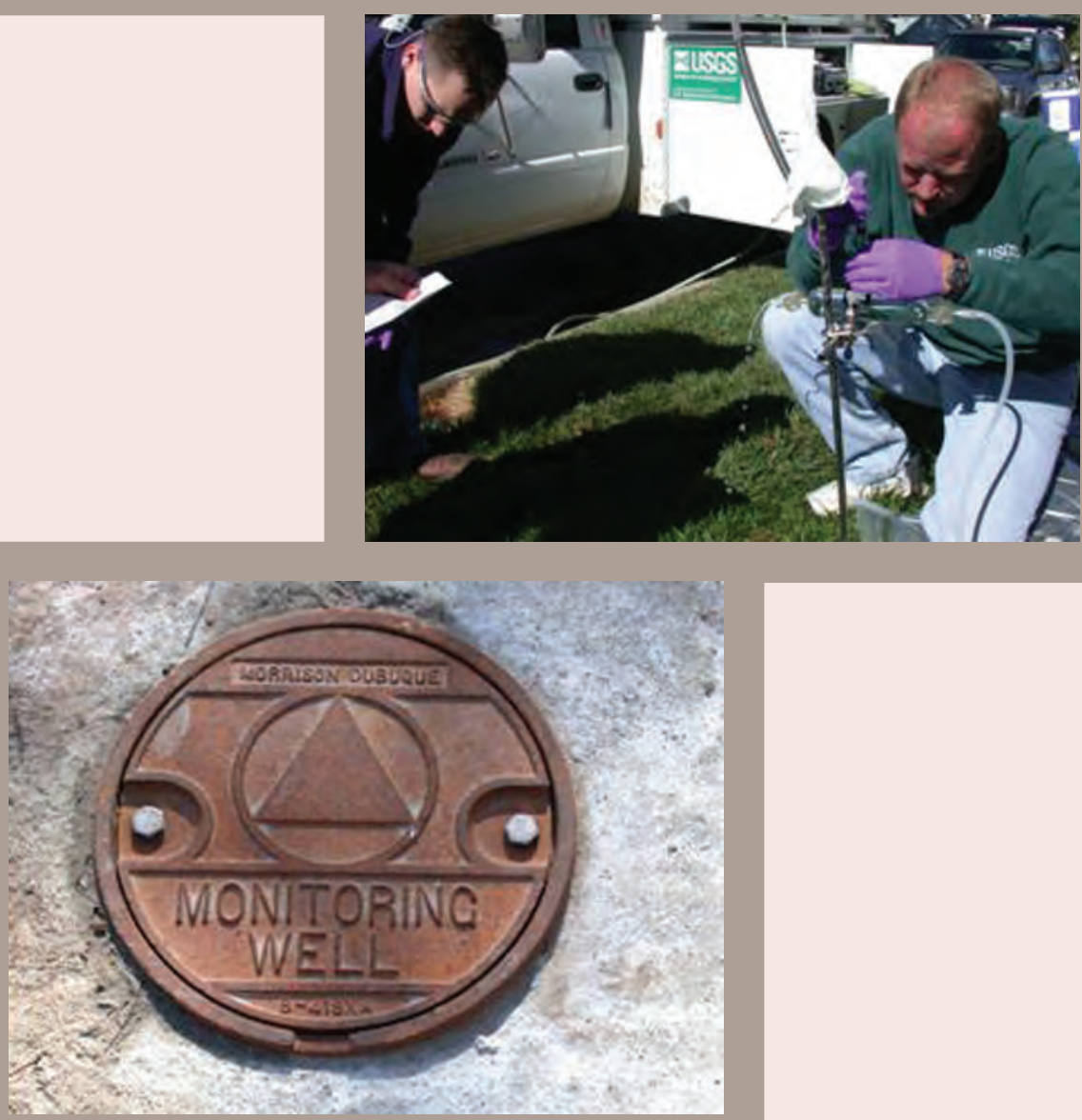